10. Резепкин А.Д. Жилища эпохи ранней бронзы. Поселение Новосвободненское // Записки ИИМК РАН № 7 / ред. Е.Н. Носов. СПб.: ИД Дмитрий Буланин, 2012. С. 39-45.

11. Резепкин А.Д., Кулькова М.А. Сравнительный петрографический анализ керамики из поселений майкопской культуры // XXX «Крупновские чтения» по археологии Северного Кавказа. Кавказ в системе культурных связей Евразии в древности и средневековье. Карачаевск, 2018. С. 131-134.

12. Поплевко Г.Н. Экспериментальное моделирование профилированной керамики // Новейшие открытия в археологии Северного Кавказа: исследования и интерпретации. XXVII Крупновские чтения: материалы междунар. науч. конф. Махачкала: ИД «Мавраевъ», 2012. С. 117-119.

13. Поплевко Г.Н. Технология изготовления майкопской керамики // Цивилизационные центры и первобытная периферия в эпоху раннего металла: модели взаимодействия: тезисы докладов круглого стола. М.: Институт археологии РАН, 2013. С. 29-31.

14. Поплевко Г.Н. Эксперименты по лепке профилированной керамики // Гістарычна-археалагічны зборнік. Вып. 28. Мн., 2013. С. 271-279.

15. Поплевко Г.Н. Разные технологические приемы ручного изготовления профилированной керамики // Верхнедонской археологический сборник. Вып. 6. Липецк: ЛГПУ, 2014. С. 151-157.

16. Поплевко Г.Н. Приемы ручной лепки круглодонной керамики по данным археологии, этнографии и экспериментального моделирования // Е.И. Крупнов и развитие археологии Северного Кавказа: мате- риалы XXVIII Крупновских чтений. М.: ФГБУН Институт археологии РАН, 2014. С. 88-91.

17. Поплевко Г.Н. Техника выколотки и ручная лепка сосудов без использования гончарного круга» // Труды IV (XX) всерос. археологического съезда в Казани. Т. І. Казань, 2014. С. 482-485.

18. Поплевко Г.Н. Об устойчивости культурной традиции в технологии изготовления керамики (на примере данных археологии и этнографии) // Культура русских в археологических исследованиях. Т. І. Омск - Тюмень - Екатеринбург, 2014. С. 118-124.

19. Поплевко Г.Н. Технология изготовления керамики в энеолите - раннем бронзовом веке на Северо-Западном Кавказе // Кавказ как связующее звено между Восточной Европой и Передним Востоком: диалог культур, культура диалога (к 140-летию Александра А. Миллера). СПб., 2015. С. 169-174.

20. Поплевко Г.Н. Некоторые приемы формовки майкопской керамики // Проблемы археологии Кавказа и Передней Азии. Баку, 2017. С. 176-199.

21. Поплевко Г.Н. Некоторые технологические приемы формовки и последующей обработки керамики по данным экспериментально-трасологических и этнографических исследований // XXX Крупновские чтения по археологии Северного Кавказа. Кавказ в системе культурных связей Евразии в древности и средневековье. Карачаевск, 2018. С. 125-128.

Работа выполнена при поддержке ФНИ ГАН, тема № 0184-2018-0009 «Взаимодействие древних культур Северной Евразии и цивилизаций Востока в эпоху палеометалла (IV тыс. до н.э. - I тыс. до н.э.)».

\title{
MORPHOLOGICAL ANALYSIS OF NOVOSVOBODNENSKAYA CULTURE CERAMICS FROM BURIALS IN THE BURIAL MOUND «KLADY»
}

(C) 2018

Rezepkin Aleksey Dmitrievich, candidate of historical sciences, senior researcher of Central Asia and Caucasus Department

Institute of History of Material Culture of the Russian Academy of Sciences (Saint Petersburg, Russian Federation)

Abstract. Morphological analysis of the ceramics of Novosobvodnenskaya culture has not been carried out so far. In this paper, 19 fragments of vessels from the burials of the burial mound «Klady» were analyzed. As a result, it was found that the composition of the clay mass used in the manufacture of ceramics was very diverse - as whole types of clays - limestone, montmorilinite, hydromica, and in their various combinations - six more variants. Almost half of the vessels (nine) were made of limestone and montmorilinite clays. The composition of impurities is also diverse: sand, chamotte, limestone and grime in various mixed versions. The last few were fragments without impurities, only four. Vessels were subjected to both oxidative roasting and reducing. Only three specimens were subjected to combined, oxidation-reduction firing. A comparative analysis of Maikop and Novosvobodnensk ceramics is carried out. Thus, this method of investigation of ceramics showed that the carriers of the Novosobvodnenskaya culture had a great experience of ceramic production, which enabled them to use a wide range of clays, in their various combinations and methods of roasting in the manufacture of ceramics.

Keywords: North Caucasus; Early Bronze Age; fourth millennium; Maikop culture; Novospobodnenskaya culture; ceramics; morphological analysis; clay species; ceramic impurity; restorative roasting; oxidizing roasting; petrographic analysis; ceramics manufacturing technology.

УДК 902.01

Статья поступила в редакцию 14.04.2018

\section{КАТАКОМБНЫЕ КУРИЛЬНИЦЫ КУРГАНОВ 1 И 4 МОГИЛЬНИКА КУНАКОВСКИЙ-2 (АНДРОПОВСКИЙ РАЙОН, СТАВРОПОЛЬСКИЙ КРАЙ)}

(C) 2018

Панасюк Наталья Викторовна, кандидат исторических наук, старший преподаватель кафедры всеобщей истории

Российский университет дружбы народов (2. Москва, Российская Федерация)

Аннотация. В статье публикуются данные о погребениях суворовской катакомбной культуры, содержащих курильницы, из могильника Кунаковский-2, исследованного экспедицией ГУП «Наследие» Ставрополь- 
ского края в 2005 году. Представлены материалы из двух курганов (1 и 4), которые ярко иллюстрируют типологическое разнообразие катакомбных ритуальных чаш и, благодаря хорошо прослеженной стратиграфической последовательности совершения погребений, позволяют построить линию их эволюции, используя выделенные на материалах восточноманычской катакомбной культуры ранние и поздние типы. Найденные в могильнике Кунаковский-2 курильницы относятся к довольно распространенным в суворовской катакомбной культуре типам I, II, VI, X, одна чаша относится к раннекатакомбному горизонту. Стратиграфические данные кургана 1 свидетельствуют о практически единовременном сооружении погребений, что подтверждается находками типологически близких курильниц. В кургане 4 выделяется не менее четырех периодов строительства, которые маркируются ритуальными чашами раннего (I, II) и позднего (VI, X) этапов. Полученные результаты позволяют обосновать для суворовской катакомбной культуры существование двух периодов развития, сопоставимых с этапами, выделенными для восточноманычской катакомбной культуры, критериями для которых являются разные типы курильниц.

Ключевые слова: археологические раскопки; курганные могильники; суворовская катакомбная культура; раннекатакомбная культура; восточноманычская катакомбная культура; курильницы; типология; стратиграфия; признаки погребального обряда; периодизация археологической культуры; эпоха средней бронзы; Ставропольский край.

Посвящается памяти друга и коллеги А.Д. Матюхина

На территории Северного Кавказа - в Закубанье и в районе верхнего течения Кубани, Кумы и Терека выделяется отдельная группа погребальных памятников катакомбной культуры эпохи средней бронзы. Своеобразие их обряда выражается в использовании Т-видных катакомб с длинной узкой шахтой и просторной камерой, доминировании вытянутого положения погребенного, а также в характерном инвентарном наборе (амфоры, биконические сосуды, бронзовые ножи, бусы, курильницы). Отличие верхнекубанских захоронений эпохи средней бронзы впервые отметила А.Л. Нечитайло [1; 2, с. 115]. Новостроечные исследования 70-х - 90-х годов прошлого столетия позволили четко обозначить характерные черты этих памятников. Специфика данных захоронений и довольно узкая их локализация на территории Западного Закубанья до верховьев р. Терек вдоль северных склонов Кавказского хребта дали основания для выделения их в отдельную суворовскую катакомбную культуру (СувКК) [3].

К сожалению, на сегодняшний день практически нет данных для разработки периодизации этой культуры, хотя время ее существования довольно продолжительно - XXV-XXIII вв. до н.э. [3, с. 189]. Решение этой проблемы невозможно без характеристики отдельных показателей погребального обряда и выявления их динамики, определяющих критерии разделения на более ранние и более поздние комплексы. Большая часть категорий инвентаря, обнаруживаемого в погребениях суворовской катакомбной культуры, как, впрочем, и в других катакомбных культурах [4, с. 161-175; 5, с. 15], слабо изменяются во времени и не могут служить хроноиндикаторами. В этой ситуации данные о развитии форм и орнаментации курильниц, являющихся яркой и неотъемлемой частью погребального обряда, могут стать одним из основных таких критериев. Типологический анализ курильниц и стратиграфические наблюдения могут стать ступенью к созданию периодизации суворовской катакомбной культуры.

Ценным источником для такого рода анализа стали материалы могильника Кунаковский-2, раскопанного экспедицией ГУП «Наследие» Ставропольского края в 2005 году на территории Андроповского района [6]. Могильник находился на заброшенном пахотном поле недалеко от одноименного хутора. В его Самарский научный вестник. 2018. Т. 7, № 3 (24) состав входили четыре кургана, вытянутые по линии запад-восток. В трех из них были исследованы погребения с курильницами. Наибольший интерес представляют собой курганы 1 и 4, где было раскопано шесть и восемь погребений с курильницами соответственно.

Курган 1 был самым крупным в могильнике, его высота достигала 1,6 м (у восточной полы), а диаметр составлял 38-40 м. Под насыпью было исследовано десять погребений, восемь из них отнесены к катакомбной культуре [6, рис. 80] (рис. 1, 2). Элементы погребальных действий схожи: Т-образная катакомба, соединение входной ямы и погребальной камеры через дромос, каменный заклад входа в камеру, вытянутое положение умерших (там, где оно восстанавливается), преимущественно в меридиональном направлении, кольцевая планировка впускных погребений. Среди разнообразного сопроводительного набора сосуды, бронзовые и стеклянные (пастовые?) бусы, бронзовый нож, астрагалы. Во впускных погребениях 4, 6, 7, 8 и 10 были найдены курильницы.

Курильницы по своему облику соответствуют традициям, известным для ритуальных чаш СувКК. В погребении 4, находившемся в центральной части кургана и имевшем катакомбную конструкцию с дромосом и каменным закладом, ритуальная чаша располагалась у черепа ребенка (кости ребенка очень плохой сохранности) [6, с. 39, рис. 110] (рис. 3: 1). Курильница представляет собой чашу на полом крестовидном поддоне, с отделением. Венчик не выделен. Внешняя поверхность черно-коричневая, с пятнами [6, с. 39, рис. 113] (табл. 1; рис. 4: 1). Кроме того, в погребении были найдены стеклянные (пастовые?) подвески с напаянными шариками и четырехрожковый бисер, шесть астрагалов и зубы мелкого рогатого скота [6, с. 39, рис. 117] (рис. 5: 1).

Коллективное погребение 6, впущенное в южную полу насыпи, имело катакомбную конструкцию (Укатакомба) без дромоса, но с каменным закладом. Входная яма погребения была частично нарушена более поздним захоронением. В результате обрушения свода катакомбы не удалось зафиксировать положение двух детей и одного взрослого, возможно уложенного «пакетом» [6, с. 42, рис. 122] (рис. 3: 2). В составе сопроводительного набора содержалось две типологически схожих курильницы. Одна из них располагалась в восточном углу погребальной каме- 
Панасюк Н.В

Катакомбные курильницы курганов 1 и 4 могильника Кунаковский-2..

07.00.00 - исторические науки и археология

ры, справа от входного отверстия. Она изготовлена довольно небрежно, ножка монолитная крестовидная, низкая, несимметричная. В стенке чаши внутри отделения имеются два грубо сделанных сквозных горизонтальных отверстия. Венчик не выделен, уплощен. Внешняя поверхность светлого, желто-коричневого цвета, слабо заглажена. Декор представляет собой узкие вертикальные параболы, нанесенные оттисками шнура. Также на стенке, противоположной отделению, находятся две волнистых линии того же шнура. Пространство между параболами заполнено оттисками квадратного штампа и небольшими дугами из оттисков шнура, ориентированными перпендикулярно параболам [6, с. 42, рис. 128-130] (табл. 1; рис. 4: 2). Другая курильница, найденная у северной стенки, также представляет собой чашу с отделением на низкой монолитной крестовидной ножке. Венчик имеет закраину вовнутрь чаши. Внешняя поверхность чаши имеет желто-коричневый цвет, внутри - черные пятна [6, с. 43, рис. 131133] (табл. 1; рис. 4: 3). В погребении также найдены жаровня из фрагмента стенки и части дна керамического сосуда, богатый набор дисковидных и цилиндрических бус и прямоугольных пронизок: бронзовые, стеклянные (пастовые?), гагатовые, костяная (?) [6, с. 43, рис. 134] (рис. 5: 2).

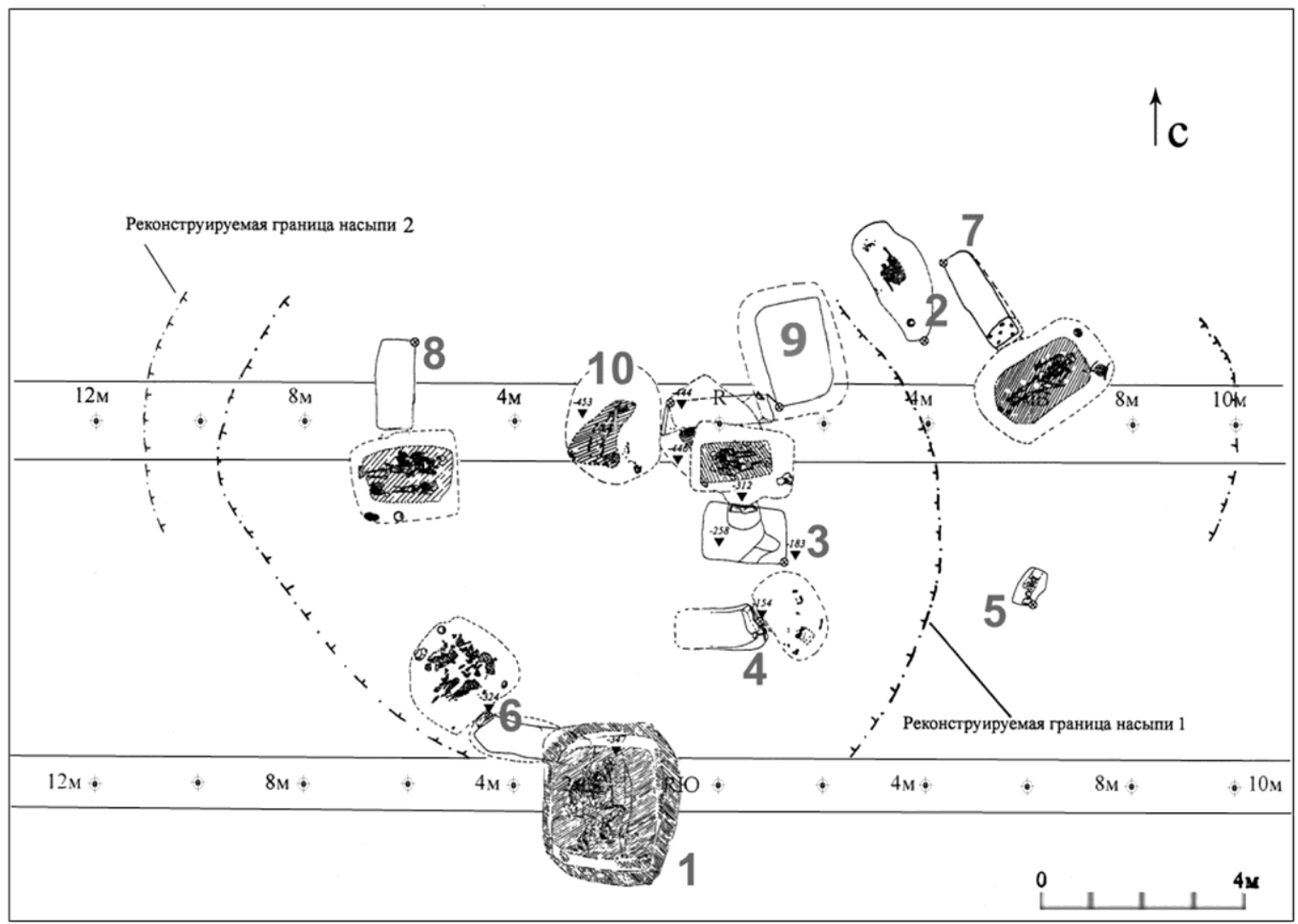

Рисунок 1 - План кургана 1 могильника Кунаковский-2 (цифрами на плане обозначены номера погребений)

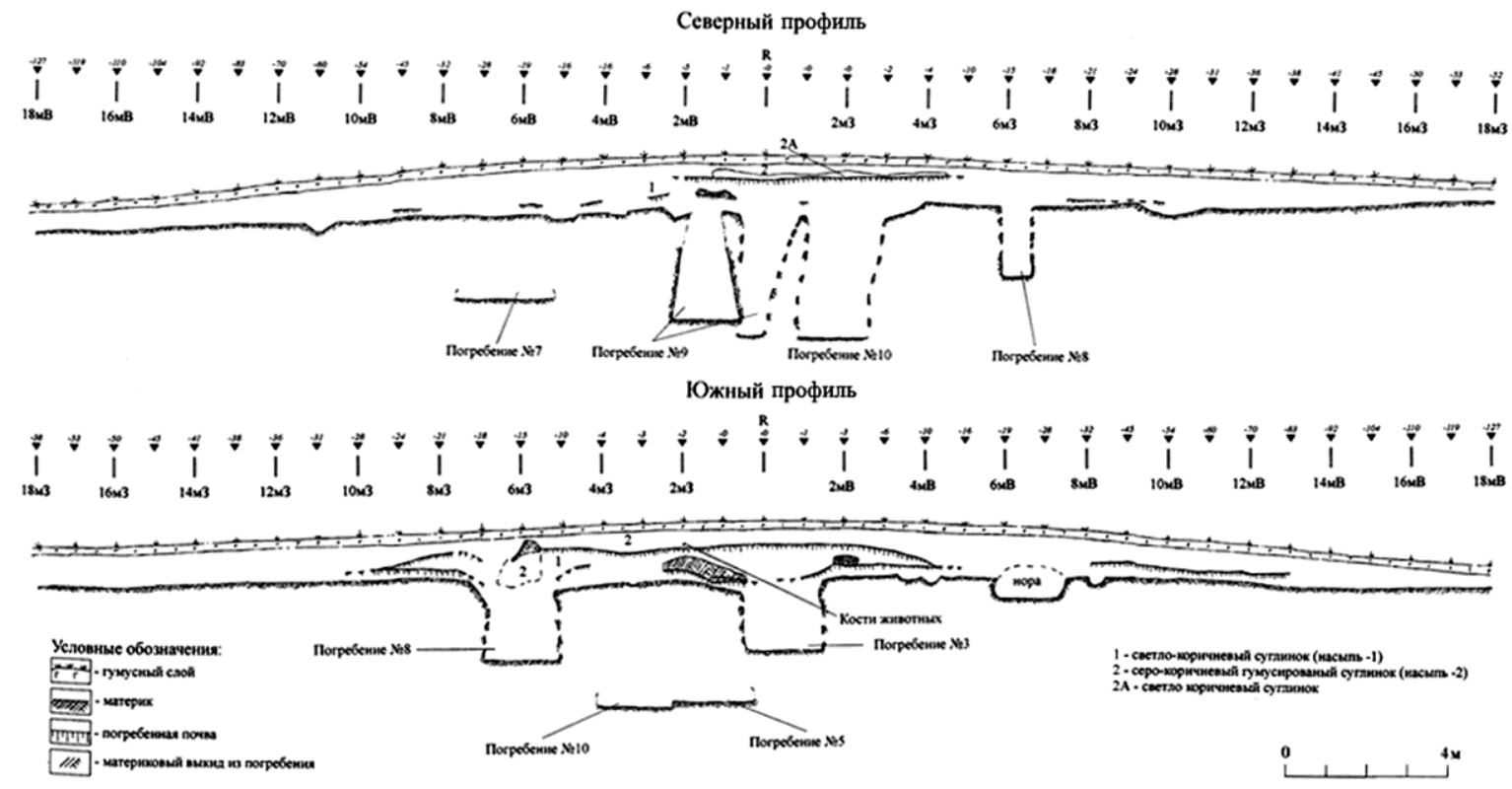

Рисунок 2 - Центральная бровка кургана 1 могильника Кунаковский-2 
В северо-восточной поле кургана находилось $п о$ гребение 7 катакомбной конструкции с дромосом, который, однако, полностью обвалился, и его размеры не восстанавливались [6, с. 45 , рис. 135] (рис. 3 : 3). Взрослый погребенный располагался вытянуто на спине. За головой погребенного стояла курильница. Внутри сосуда находились древесные угольки. Это чаша с отделением на полой крестовидной ножке. Венчик имеет небольшую закраину внутрь чаши. Поверхность сосуда заглажена, коричневого цвета с черными вертикальными потеками. Верхний срез венчика чаши украшен прочерченным зигзагом, который с внешней стороны заполнен оттисками треугольного штампа. По верхнему срезу отделения нанесены только треугольные вдавления. Боковая поверхность чаши орнаментирована двумя горизонтальными прочерченными линиями под венчиком, каждая из которых снизу сопровождается линией треугольных оттисков. На боковой поверхности ножек нанесены вертикальные линии треугольного штампа, одна из линий достигает уровня пояска на чаше. В этом месте также читаются слабые круглые оттиски [6, с. 46, рис. 145-146] (табл. 1; рис. 4: 4). Кроме того, в камере находились остатки деревянного блюда с бронзовым ножом и скоплением костей крупного животного, скопление бус и бисера, бронзовая подвеска и, предположительно, серебряная проволока и обсидиановый отщеп [6, с. 45-47, рис. 150] (рис. 5: 3).

Погребение 8, являвшееся основным для второй насыпи кургана, было коллективным (взрослый и ребенок). Катакомбное сооружение имело дромос и каменный заклад [6, с. 48, рис. 152] (рис. 6: 1). Вероятно, взрослый умерший был перезахоронен, о чем свидетельствует характер расположения костей. Вокруг погребенных располагались черепа мелкого рогатого скота, 100 астрагалов, бронзовые бусины и каменный предмет («наковаленка»?) [6, с. 50, рис. 164] (рис. 7: 1). Курильница стояла у южной стенки, у коленей ребенка. Это чаша с крупным подквадратным отделением на низкой монолитной крестовидной ножке. Сосуд не слишком хорошей сохранности, что, возможно, связано с не очень высоким качеством его изготовления. Орнамент на венчике представляет собой оттиски тройного шнура, образующие зигзаг, заполненный круглым штампом. Внешняя поверхность украшена четырьмя шевронами из двух или трех вписанных друг в друга оттисков тройного шнура, площадь между которыми заполнена круглым штампом. Расстояние между этими шевронами в одном случае заполнено крестом из оттисков тройного шнура. Нижняя плоскость ножек покрыта по периметру тройным шнуром, внутри пять оттисков круглого штампа [6, с. 49, рис. 162] (табл. 1; рис. 7: 2).

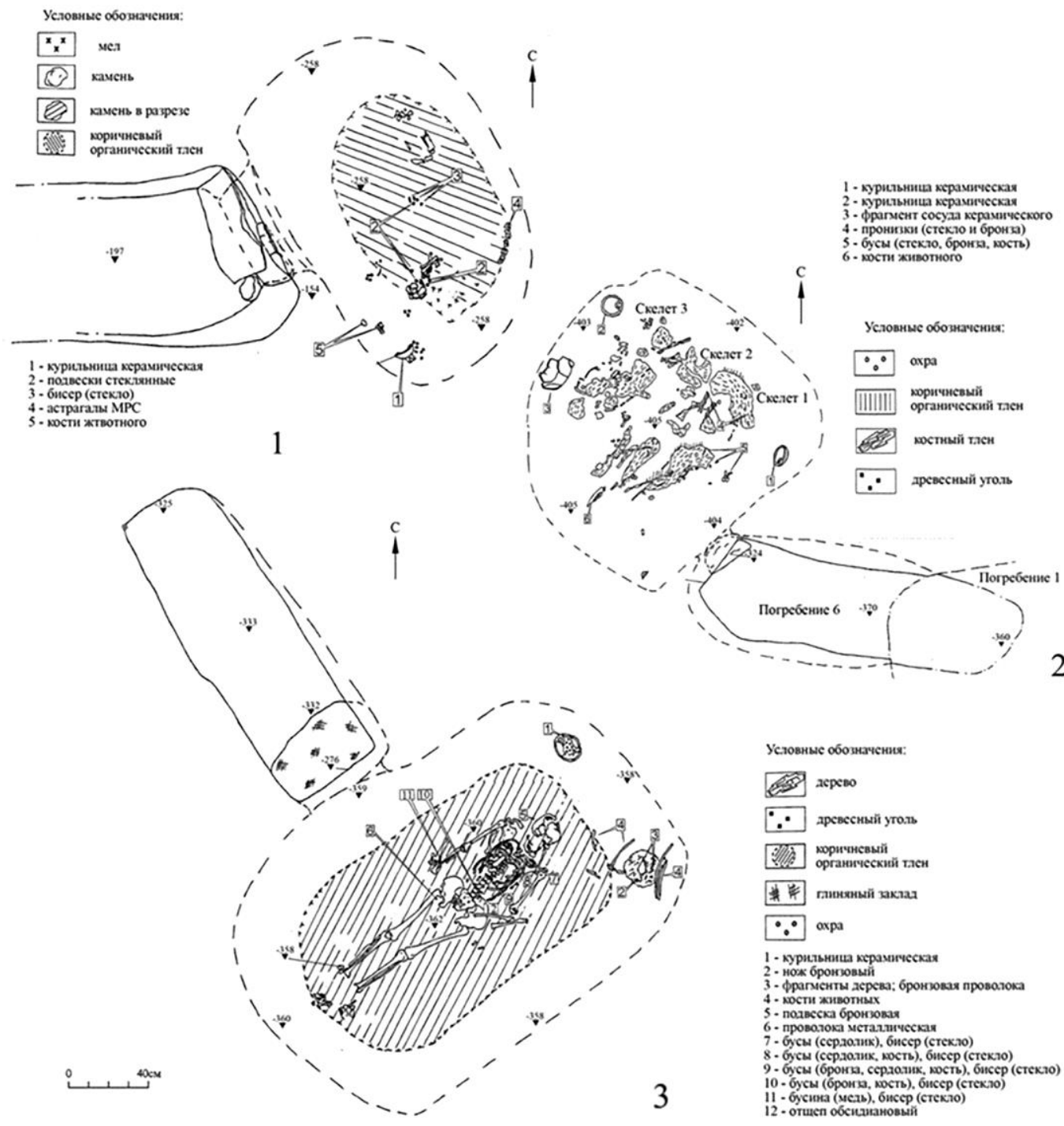

Рисунок 3 - Планы погребений кургана 1 могильника Кунаковский-2: 1 - погребение 4; 2- погребение 6; 3- погребение 7 
Основными для первой насыпи являлись погребения 9 и 10 (последнее с курильницей), они находились в центре кургана и, возможно, представляли собой единую конструкцию. Погребение 10 очень плохой сохранности: четко читалась только придонная часть камеры, костяк взрослого, расположенный вытянуто на спине, и кости животного практически полностью истлели, бронзовые и стеклянные (пастовые?) бусы представлены во фрагментах, курильница сохранилась лишь частично [6, с. 52, рис. 166] (рис. 6: 2). Она располагалась в юго-восточном углу погребальной камеры и представляет собой сосуд на монолитной крестовидной ножке. Стенки довольно толстые, курильница грубой лепки. Внешняя поверхность кирпичного цвета, украшена рядами точечных наколов, которые на боковой поверхности чаши дополняются двумя глубокими горизонтальными прочерченными линиями [6, с. 53, рис. 174] (табл. 1; рис. 7: 3).

Из десяти погребений эпохи средней бронзы кургана 4 одно погребение (п. 3), видимо, следует относить к раннекатакомбному горизонту, остальные связаны с суворовской катакомбной культурой (рис. 8, 9). Отличает их от погребений кургана 1 лишь появление слабо скорченного положения умерших (п. 3, $4,5)$. Курган 4 находился на краю могильника, практически на склоне. Его высота достигала 1,8 м, видимый диаметр - 40 м. Небольшая часть насыпи осталась неисследованной, т.к. по южной поле кургана проходила труба газопровода. В восьми захоронениях были обнаружены курильницы.

В центральной части кургана находилось раннекатакомбное погребение 3, которое было основным для второй насыпи (погребений, связанных с первой насыпью, обнаружить не удалось). Конструкция погребения - У-катакомба с дромосом и закладом из камня и глины [6, с. 89-90, рис. 300] (рис. 10: 1). Дромос соединялся с камерой вертикальной ступенью высотой 38 см. Умерший располагался скорченно на спине, вероятно, на органической подстилке (сохранился коричневый тлен). В районе стоп погре- бенного находилось два пятна охры («следы стоп»), на запястье - набор бронзовых цилиндрических бус, на уровне плеч стояла курильница плохой сохранности. Это чаша без отделения на низкой крестовидной полой ножке. Венчик уплощен. Поверхность чаши не орнаментирована, светлого, желто-коричневого цвета с черными пятнами копоти. Декорирован только верхний срез венчика двойными или тройными прочерченными линиями, образующими зигзаг [6, с. 91 , рис. 308-310] (табл. 1; рис. 11: 1).
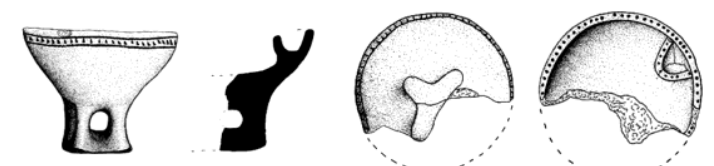

1
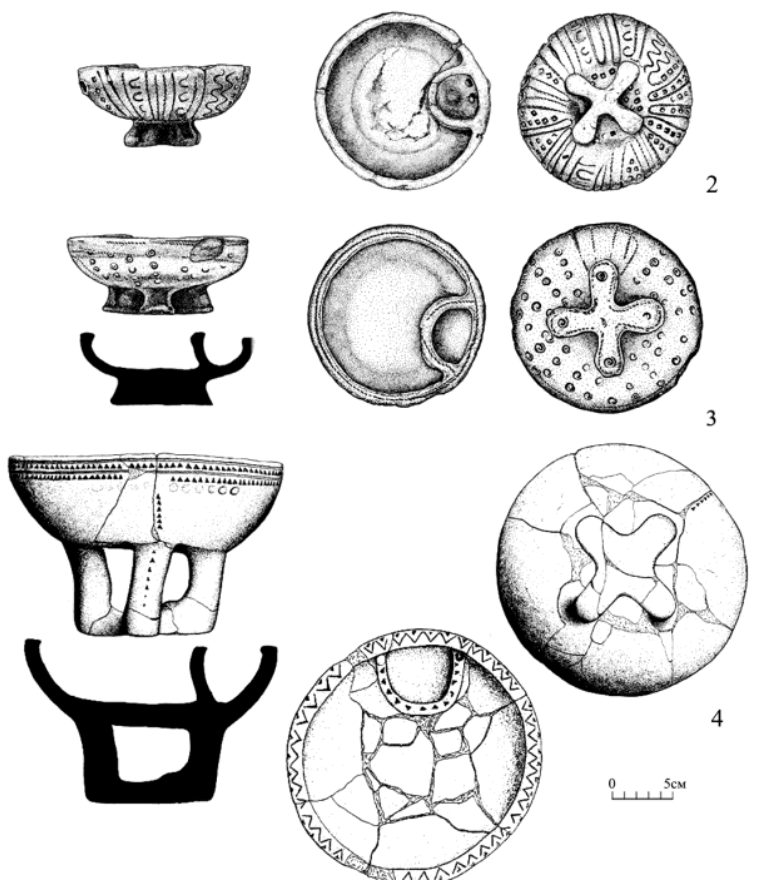

Рисунок 4 - Курильницы из кургана 1 могильника Кунаковский-2: 1 - погребение 4; 2 - погребение 6 (находка 1); 3- погребение 6 (находка 2); 4- погребение 7; 1-4- керамика
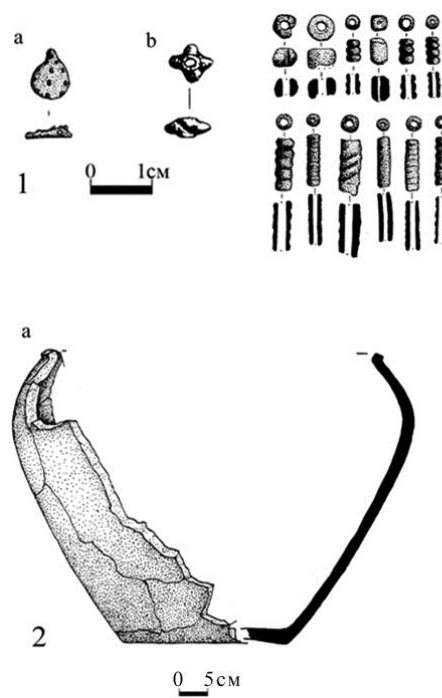

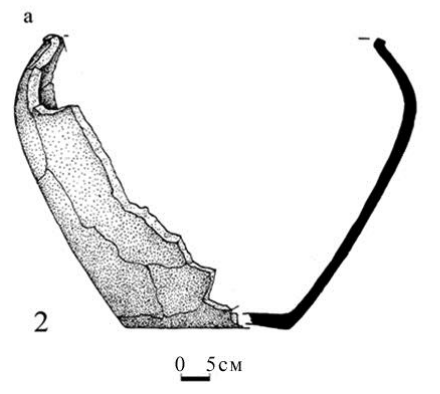

Рисунок 5 - Находки из погребений кургана 1 могильника Кунаковский-2:

1 - погребение 4 ( $a$ - подвески; $b$ - бисер); 2 - погребение 6 ( $a$ - сосуд; $b$ - бусы и пронизки (стекло, бронза, кость); 3 - погребение 7 ( $a-$ бусы (бронза, сердолик, кость); бисер; $b$ - отщеп обсидиановый; $c$ - проволока металлическая; $d$ - подвеска бронзовая; $e$ - нож бронзовый; $f$-бусы сердоликовые, бисер; $g$ - проволока бронзовая); 1, 2b, 3a, $3 f$-паста; 2a-керамика; 2b, 3a, 3d, 3e, $3 g$-бронза; 3a, 3b, 3f- камень 
Курильница из впускного погребения 4 также плохой сохранности - части ножки, венчика и чаши утрачены. Погребение зафиксировано в южной поле кургана и представляло собой Т-катакомбу с каменным закладом [6, с. 91-92, рис. 312] (рис. 10: 3). Костяк очень плохой сохранности, предположительно, лежал вытянуто на левом боку со слабо скорченными в коленях ногами. В камере находился следующий инвентарь: сферический сосуд с ручкой (рис. 11: $3)$, череп мелкого рогатого скота, на пояснице - набор бисера, синеватая стеклянная (?) четырехлучевая и сердоликовая дисковидная бусины (пояс?) [6, c. 93, рис. 319] (рис. 11: 4), в районе черепа справа от входа - курильница. Это сосуд с отделением на монолитной крестовидной ножке. Венчик уплощен, имеет явно выраженную закраину вовнутрь чаши. Поверхность заглажена, серо-желтого цвета, внутри закопчена. Чаша была заполнена углями [6, с. 93 , рис. 321-323] (табл. 1; рис. 11: 2).
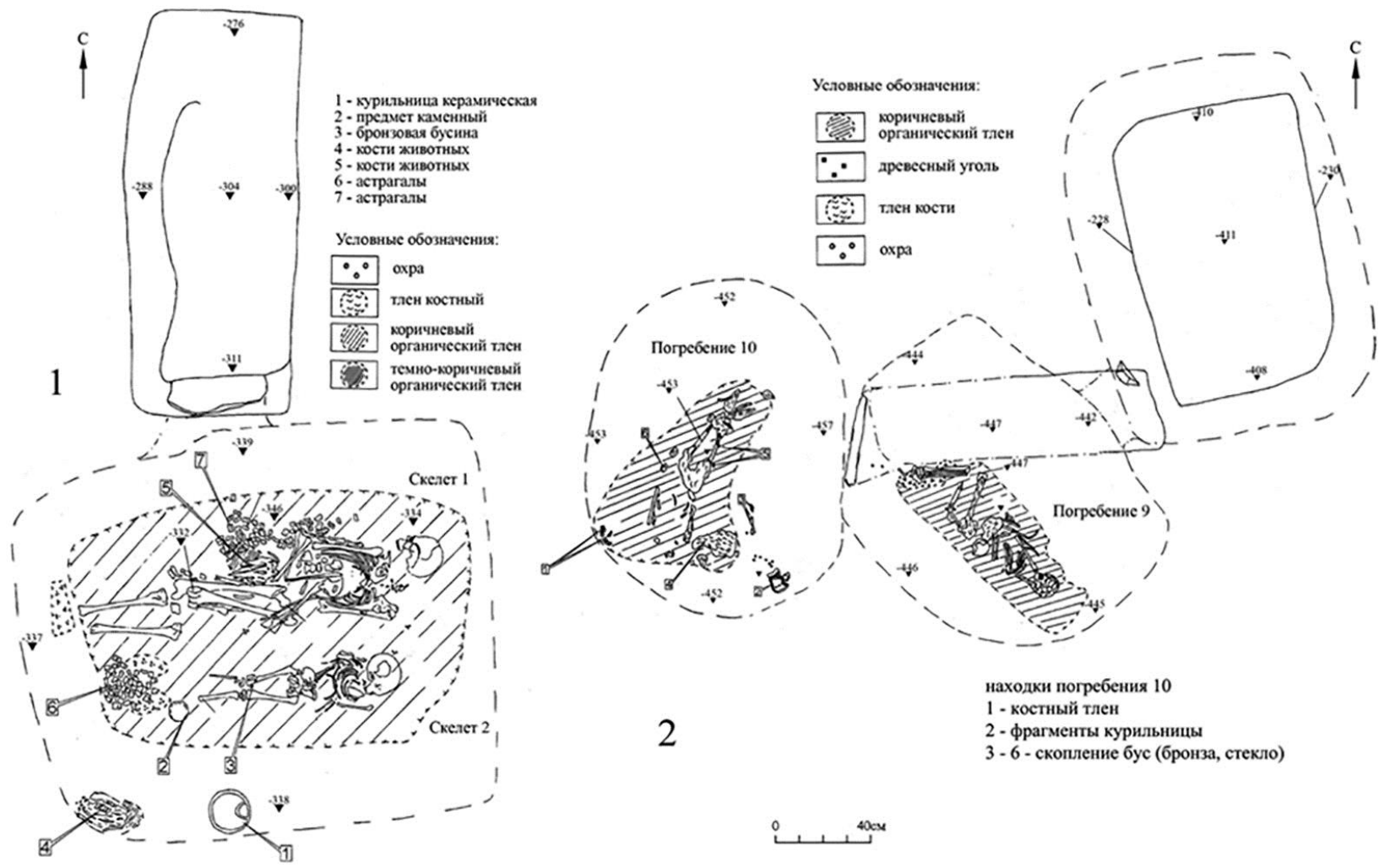

Рисунок 6 - Планы погребений кургана 1 могильника Кунаковский-2: 1- погребение 8; 2- погребение 10

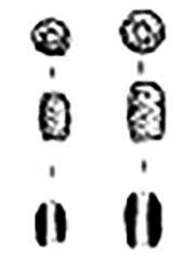

$\mathbf{a}$
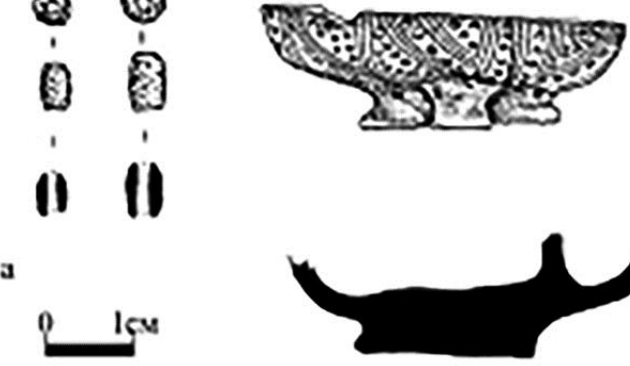

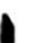
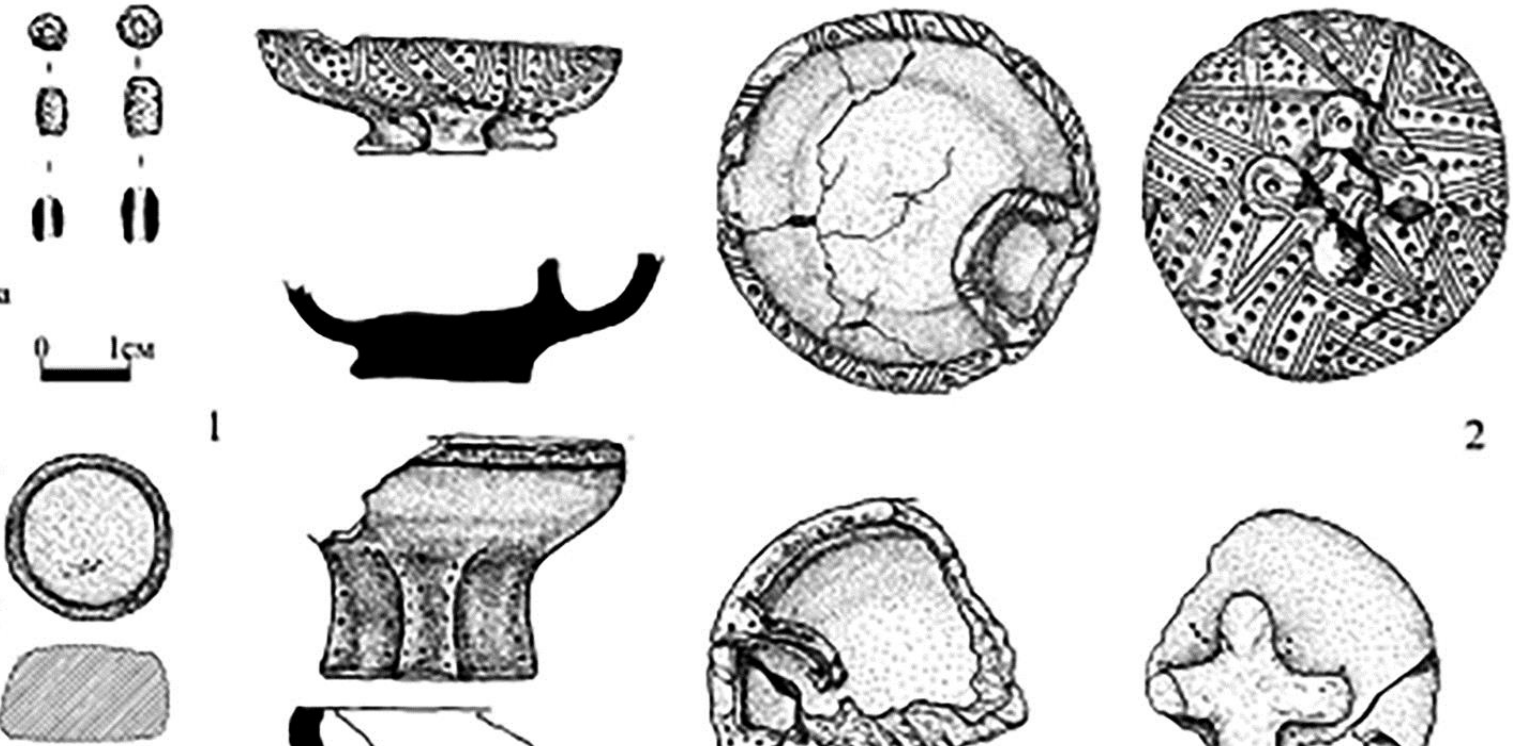

1

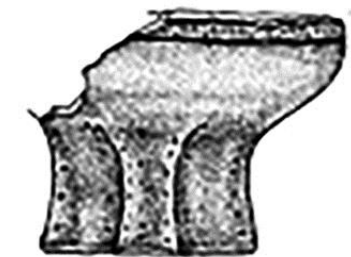

b
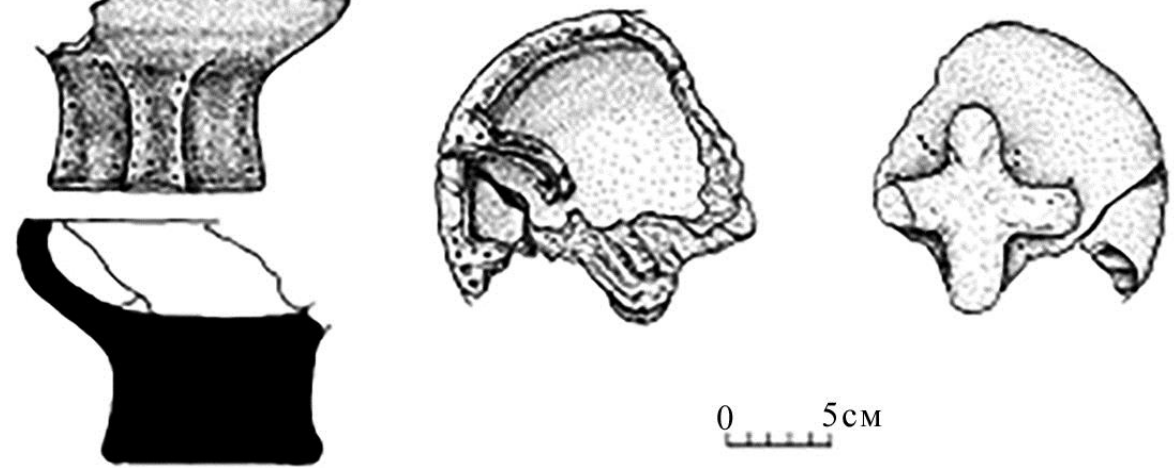

Рисунок 7 - Находки из погребений кургана 1 могильника Кунаковский-2:

1 - погребение 8 ( $a$ - бусина; $b$ - наковаленка); 2- курильница из погребения 8;

3- курильница из погребения 10; 1a-бронза, 1b-камень, 2, 3-керамика 
К югу от описанного захоронения находилась группа погребений, наслоившихся друг на друга. Самым последним, вероятно, явилось погребение 5, частично перекрывшее камеру соседнего п. 6. Из конструктивных особенностей были зафиксированы только придонная часть входной ямы, камни заклада и просевшая яйцевидная камера [6, с. 94, рис. 324] (рис. 10: 2). Рядом с тазом умершего, располагавшегося слабо скорченно на правом боку, слева от входа стояла серо-коричневая курильница на четырех невысоких раздельных ножках, с отделением и сквозным горизонтальным отверстием в стенке чаши внутри отделения. Венчик уплощен, имеет незначительное утолщение. Внутри курильницы обнаружены угли. Сосуд богато орнаментирован по всей поверхности: по верхнему срезу венчика чаши и отделения нанесены оттиски шнура в виде зигзага; на внешней поверхности чаши и ножек располагаются четыре шеврона из нескольких рядов шнуровых оттисков, спускающиеся по ножкам и заполненные круглыми вдавлениями. Пространство между ножками на дне чаши также заполнено тремя линиями шнура. Фестоны из четырех рядов шнуровых оттисков украшают внешнюю стенку отделения [6, с. 95 , рис. 331-332] (табл. 1; рис. 12: 1).

Парное детское погребение 6 находилось рядом с предыдущим и нарушило погребение 7, в связи с чем стенки могильного сооружения плохо читались. Особенности заполнения камеры погребения 6 («язык» чернозема в материковой глине) позволяют предположить, что второй умерший был подзахоронен. Сохранность двух детских костяков очень плохая, положение полностью не восстанавливается вероятно, они лежали вытянуто на спине, головами на юг [6, с. 95-96, рис. 333] (рис. 10: 4). Сильно фрагментированная курильница находилась у входа в погребальную камеру. Форма полностью не восстанавливается, по мнению автора отчета, чаша имела крестовидную полую ножку. Сохранившиеся части венчика, чаши и ножек имеют декор в виде круглых вдавлений (табл. 1; рис. 12: 2). Кроме того, в погребении был обнаружен сосуд с ручкой, на тазовых костях обоих детей - наборы бисера [6, с. 96 , рис. 345] (рис. 13: 1-2).

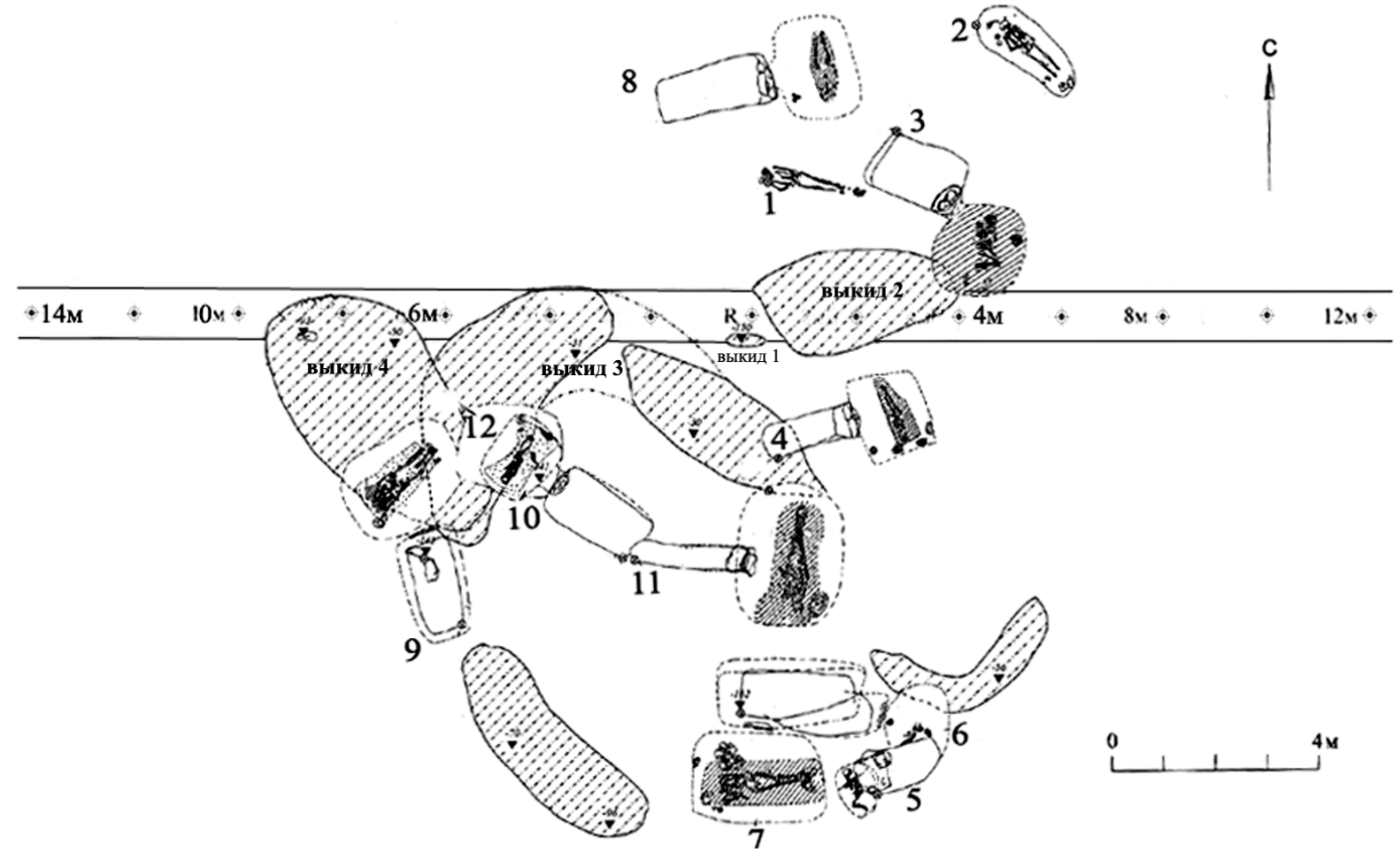

Рисунок 8 - План кургана 4 могильника Кунаковский-2 (цифрами на плане обозначены номера погребений)

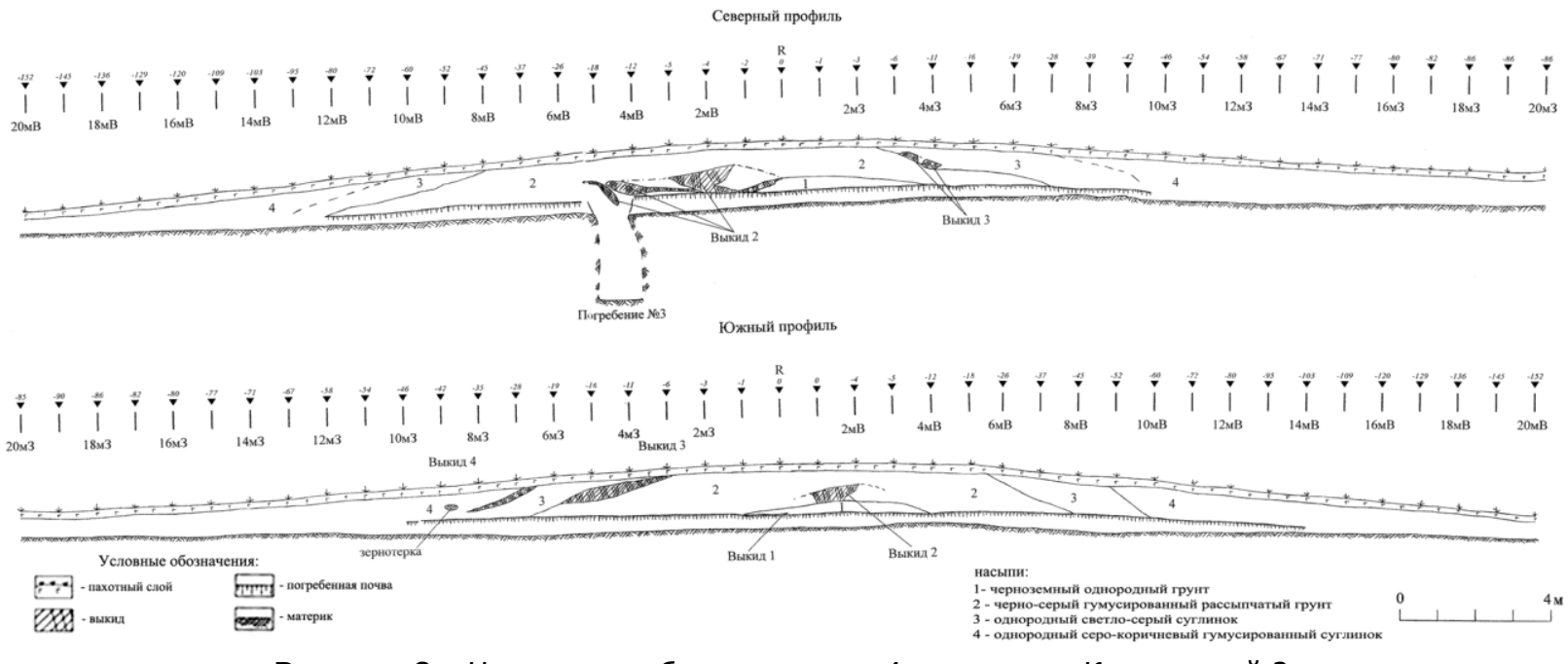

Рисунок 9 - Центральная бровка кургана 4 могильника Кунаковский-2 
Необычную форму имеет курильница из погребения 7, вероятно основного для четвертой насыпи. Возможно, с этим погребением связан выкид в югозападной поле кургана (рис. 8). Погребение представляло собой катакомбу, однако форма и высота конструктивных элементов четко не фиксировались из-за сооружения более позднего погребения 6. В могиле находился взрослый вытянуто на спине, костяк практически истлел. В районе стоп находились два пятна охры [6, с. 97-98, рис. 333] (рис. 10: 4). 3а черепом погребенного располагались курильница и керамический сосуд [6, с. 99, рис. 350] (рис. 13: 3).
Курильница на четырех раздельных невысоких ножках, расположенных в центре, с отделением, напротив него на внешней стороне стенки чаши есть фигурная «ручка» со сквозными вертикальными отверстиями. Поверхность заглажена, серо-коричневого цвета с черными пятнами копоти, покрыта декором из треугольников, нанесенных тройными оттисками шнура, пространство между ними и внутри заполнено вдавлениями спирального штампа. Оттиски спирального штампа частично покрывают плоскость между ножками [6, с. 99, рис. 346-347] (табл. 1; рис. 12: 3).
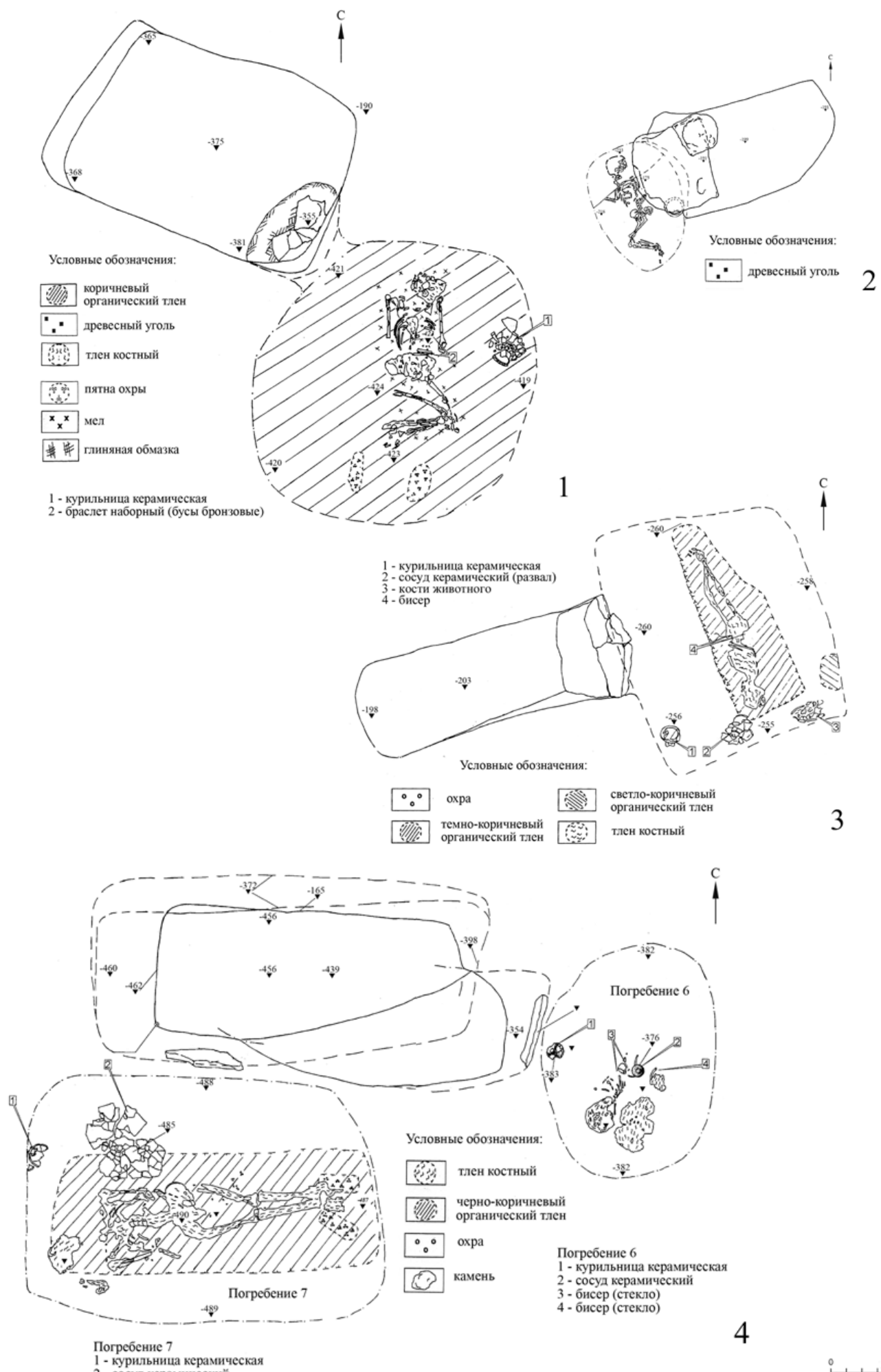

1 - курильница керамичесі
2 - сосуд керамический

Рисунок 10 - Планы погребений кургана 4 могильника Кунаковский-2:

1- погребение 3; 2- погребение 5; 3- погребение 4; 4- погребения 6 и 7 


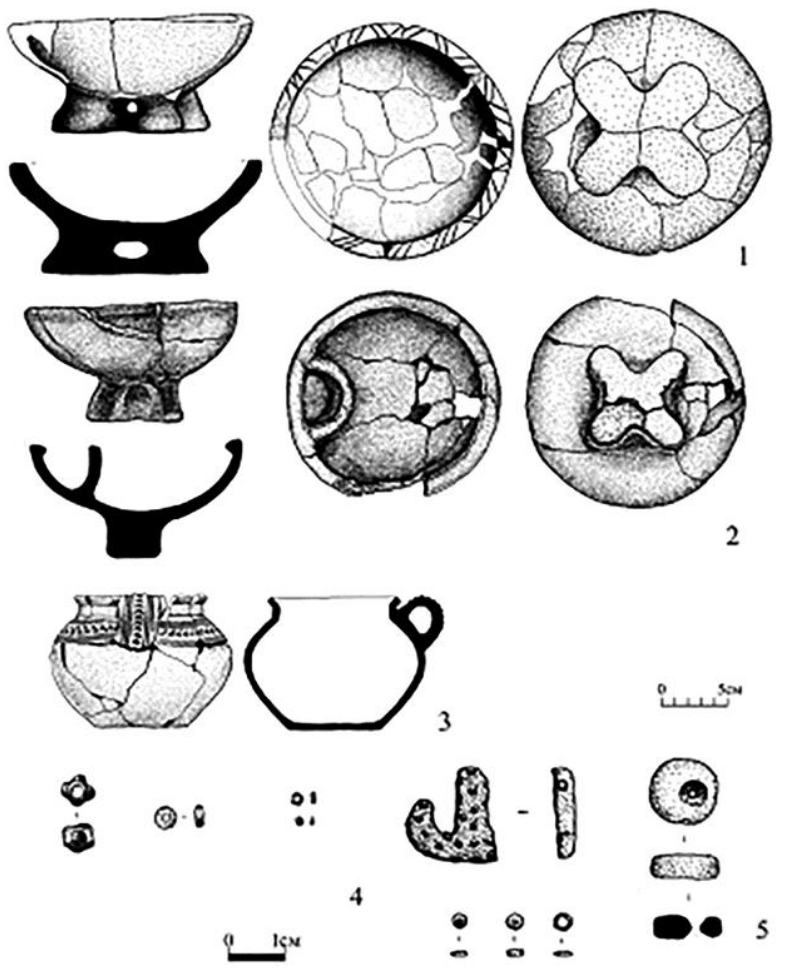

Рисунок 11 - Находки из кургана 4 могильника Кунаковский-2: 1 - курильница из погребения 3; 2-4- погребение 4 (2 - курильница; 3- сосуд; 4- бисер); 5- подвеска и бусы из погребения 12; 1-3- керамика, 4, 5- паста

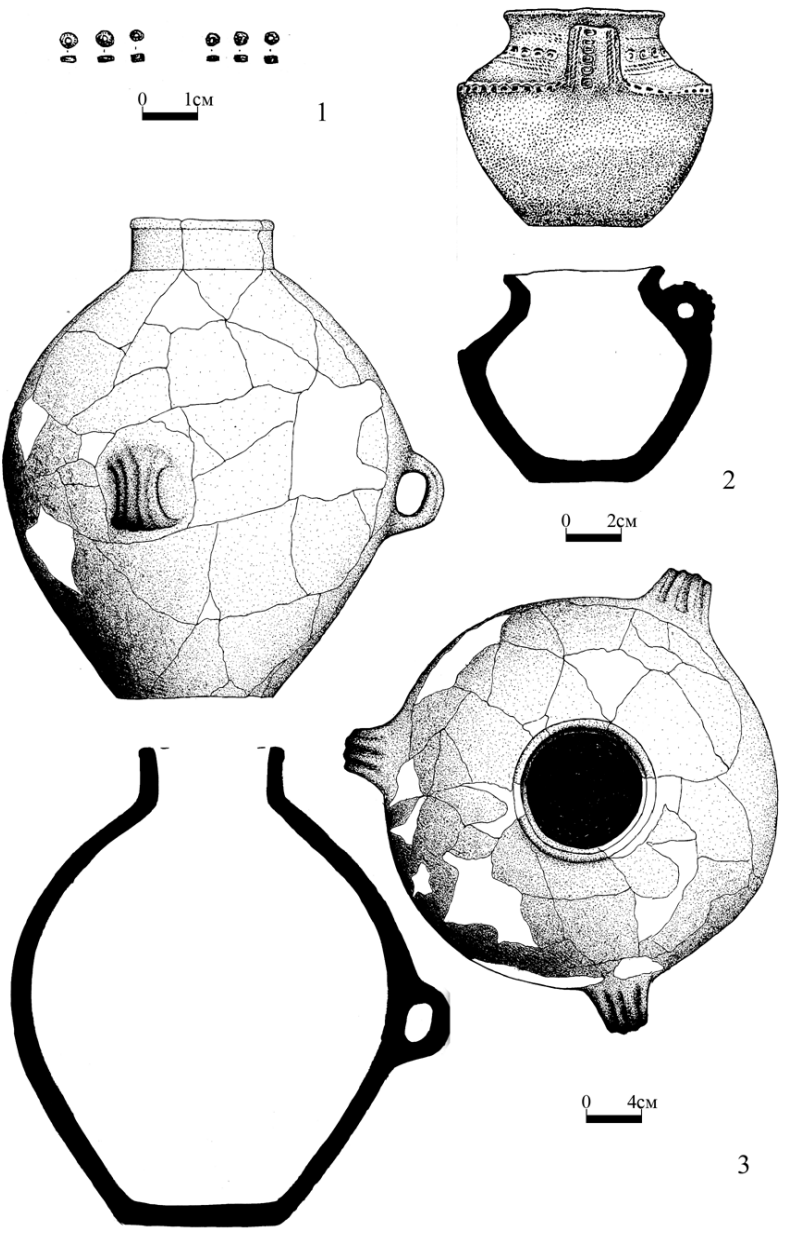

Рисунок 13 - Находки из погребений кургана 4 могильника Кунаковский-2:

1-2- погребение 6 (1- бисер; 2- сосуд);

3- сосуд из погребения 7; 1 - паста, 2, 3- керамика
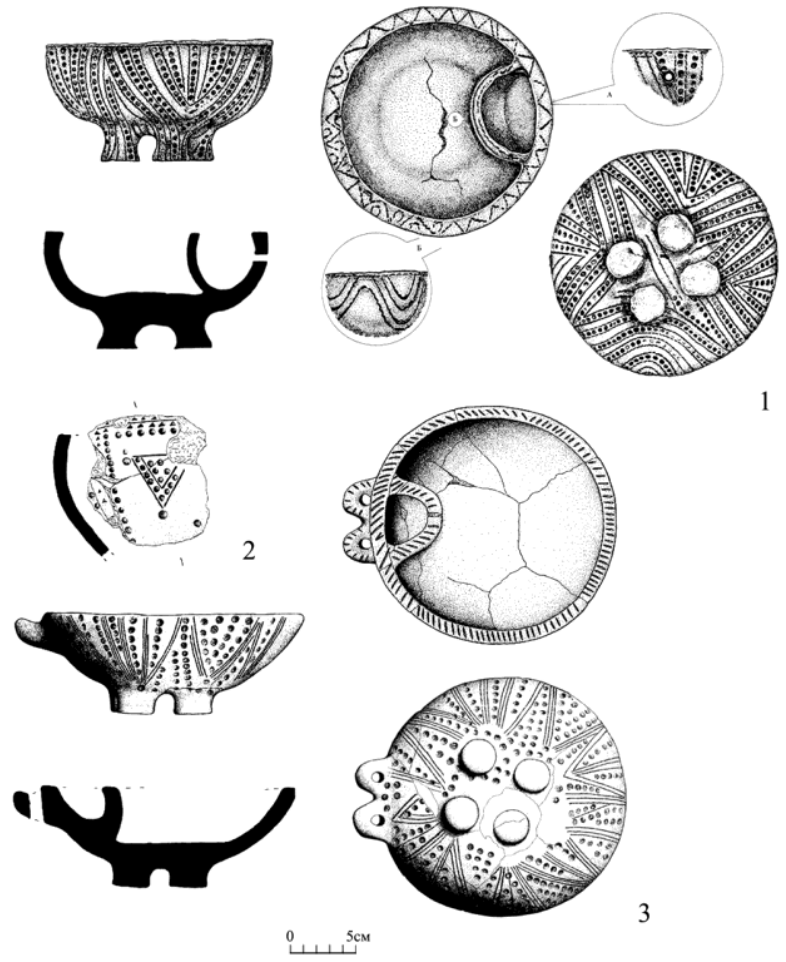

Рисунок 12 - Курильницы из кургана 4 могильника Кунаковский-2:

1 - погребение 5; 2- погребение 6;

3- погребение 7; 1-3- керамика

В северную полу кургана было впущено погребение 8, имевшее Т-катакомбную конструкцию. Останки человека представлены костным тленом, располагались, предположительно, вытянуто на спине [6, c. 99-100, рис. 352] (рис. 14: 1). В районе груди погребенного зафиксировано пятно красной охры, на шее и в районе плеча лежал бисер коричневого и белого цвета, а также одна каменная бусина, в юговосточном углу камеры [6, с. 101, рис. 357], справа от входа в направлении черепа находилась курильница на полом крестовидном поддоне. Крупная чаша с отделением (от него сохранились основания стенки) красно-кирпичного цвета, венчик уплощен, имеет небольшую закраину внутрь. Внутри находились угли. Схема орнамента типична для суворовских курильниц: украшен верхний срез венчика, на внешней поверхности чаши под венчиком имеется орнаментальный «поясок». Ниже нанесены небольшие прочерченные треугольники вершинами вниз, заполненные оттисками треугольного штампа. От «пояска» вниз, по ребру ножек нанесены вертикальные прочерченные линии, окантованные треугольными оттисками, между линиями идет ряд круглых вдавлений [6, с. 101, рис. 360-361] (табл. 1; рис. 15: 1).

С погребением 11, которое находилось в центральной части, связано сооружение третьей насыпи кургана. Оно сопровождалось мощным выкидом материковой глины серповидной формы (рис. 8, 9). Погребение представляло собой Т-катакомбу с каменным закладом [6, с. 104-106, рис. 372] (рис. 14: 2). Курильница располагалась слева от входа, в направлении ног погребенного (от него сохранился только костный тлен, видимо, лежал вытянуто на спине), в северо-западном углу камеры. Она представляет собой чашу с отделением на крестовидной полой довольно высокой ножке. Венчик уплощен, немного 
загнут внутрь чаши. Поверхность заглажена, коричневого цвета с пятнами черного прокала. Внутри сосуда сохранились угли. Верхний срез венчика и отделения украшен двумя рядами оттисков треугольного штампа, расположенных по краю. На внешней поверхности под венчиком нанесена резная линия, под ней - три ряда оттисков треугольного штампа, ниже - треугольники вершинами вниз, образованные такими же оттисками $[6$, с. 106 , рис. $379-380]$ (табл. 1; рис. 15: 2). За черепом зафиксирован коричневый органический тлен - вероятно, остатки деревянного блюда, в районе шеи находился бисер.

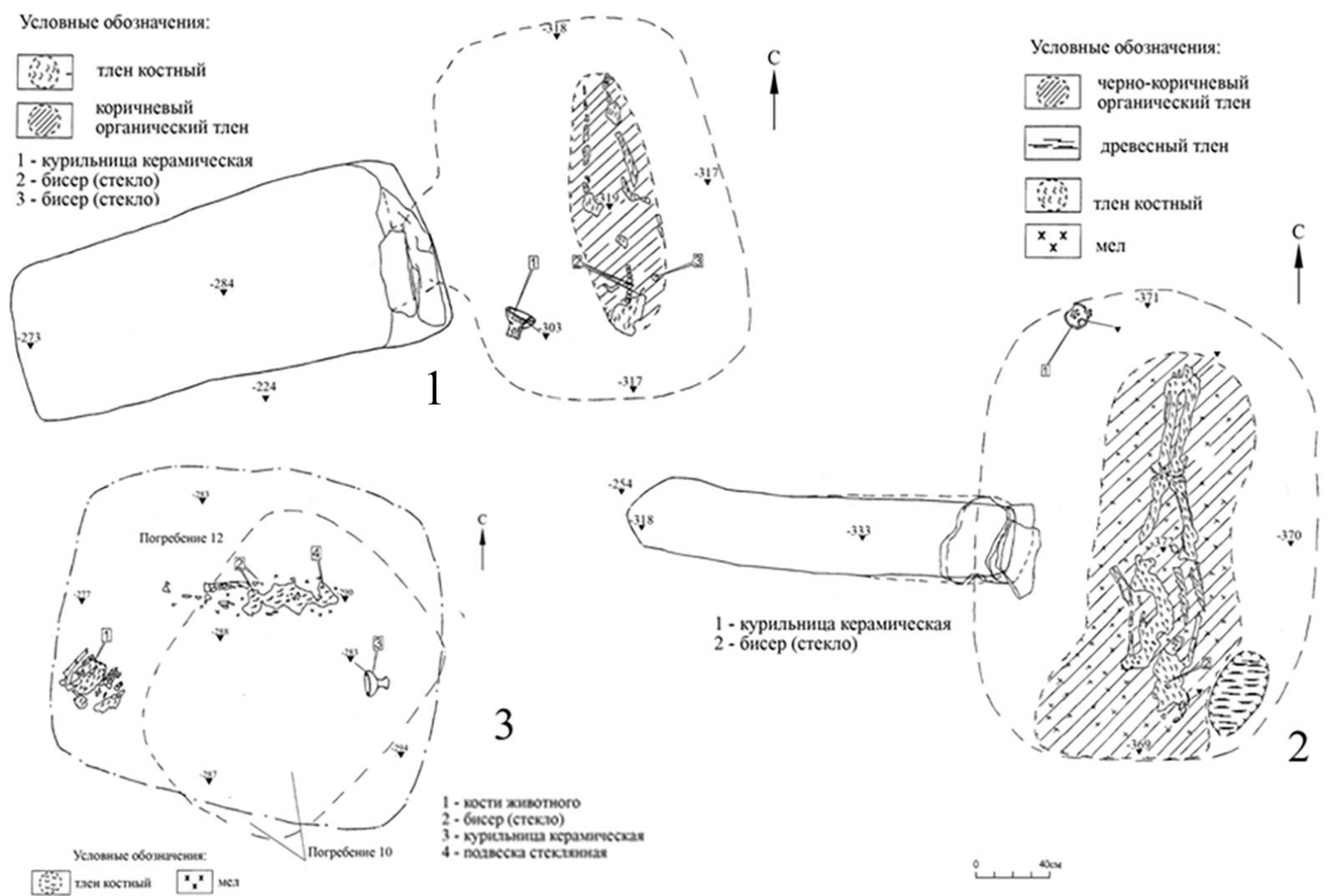

Рисунок 14 - Планы погребений кургана 4 могильника Кунаковский-2: 1 - погребение 8; 2- погребение 11; 3- погребение 12
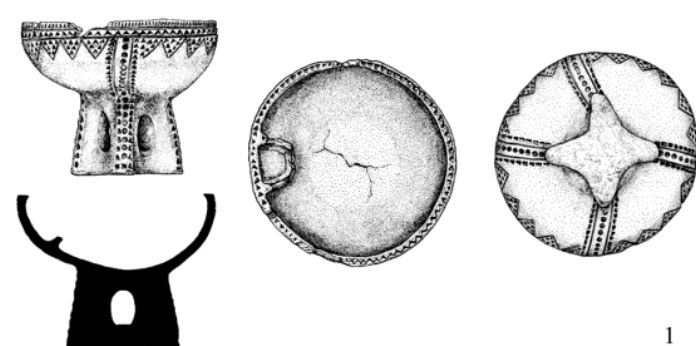

1
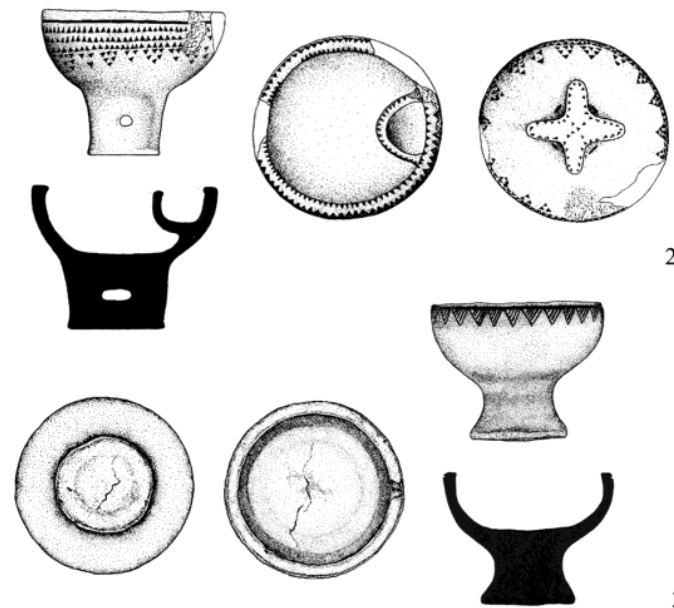

$0.5 \mathrm{~cm}$

3

Рисунок 15 - Курильницы из кургана 4 могильника Кунаковский-2: 1 - погребение 8; 2- погребение 11; 3- погребение 12; 1-3- керамика
В насыпь, совершенную над захоронением 11 , было впущено погребение 12, чья конструкция практически не читалась. Стенки ямы прослеживались плохо, заполнение состояло из мешаного грунта. В могиле находились останки маленького ребенка (у него были молочные зубы) вытянуто на спине, очень плохой сохранности [6, с. 106-107, рис. 382] (рис. 14: 3). В камере найдены череп мелкого рогатого скота, наборный пояс из бисера, стеклянная (?) подвеска [6, c. 107, рис. 383]. У восточной стенки ямы в 25 см от головы умершего находилась курильница без отделения на цельной круглой ножке. Ножка утолщается к низу, что придает всей курильнице рюмковидную форму. Венчик не выделен. Чаша серо-коричневого цвета, с черными потеками [6, с. 107, рис. 386-387] (табл. 1; рис. 15: 3).

Все исследованные курильницы, за исключением раннекатакомбной чаши из погребения 3 кургана 4, типичны для суворовской катакомбной культуры [7] и для катакомбных древностей в целом [8]. Они относятся к типам I, II, VI, X согласно разработанной автором типологии (табл. 2). Первые два типа являются наиболее характерными и самыми распространенными для катакомбных древностей; типы VI и X встречаются реже, однако представляются довольно выразительными маркерами позднего этапа [9]. Итак, даже в рамках одной курганной насыпи мы видим значительное разнообразие курильниц, что подтверждает их разновременное появление и применение в погребальном обряде. 
Панасюк Н.В.

Катакомбные курильницы курганов 1 и 4 могильника Кунаковский-2...

07.00.00 - исторические науки и археология

Таблица 1 - Курильницы могильника Кунаковский-2

\begin{tabular}{|c|c|c|c|c|c|c|c|c|c|}
\hline № к & № П & $\begin{array}{c}\text { Степень } \\
\text { сохранности }\end{array}$ & $\begin{array}{l}\text { Форма } \\
\text { ножки }\end{array}$ & Отд-ие & h, cM & $\mathrm{d}, \mathrm{cm}$ & Орнамент & Зоны декора & Тип \\
\hline 1 & 4 & $\begin{array}{c}\text { треть чаши } \\
\text { утрачена }\end{array}$ & $\begin{array}{c}\text { полый } \\
\text { крест }\end{array}$ & да & 9,5 & 12,5 & $\square+\boldsymbol{\mapsto + \square}$ & $\begin{array}{c}\text { срез венчика, } \\
\text { «поясок» }\end{array}$ & $\mathrm{II} / 3$ \\
\hline 1 & 6 & целая & крест & да & 6,6 & 14,8 & $\square+\cup$ & чаша снаружи & $\mathrm{I} / 2$ \\
\hline 1 & 6 & целая & крест & да & 6,0 & 14,8 & $\square+9$ & $\begin{array}{c}\text { срез венчика, } \\
\text { чаша снаружи, } \\
\text { низ ножек }\end{array}$ & $\mathrm{I} / 1$ \\
\hline 1 & 7 & целая & $\begin{array}{c}\text { полый } \\
\text { крест }\end{array}$ & да & 11,0 & 17,0 & $\wedge+\boldsymbol{\Lambda}$ & $\begin{array}{c}\text { срез венчика, } \\
\text { «поясок», бок } \\
\text { ножек }\end{array}$ & $\mathrm{II} / 2$ \\
\hline 1 & 8 & $\begin{array}{c}\text { часть венчика и } \\
\text { ножек утрачены }\end{array}$ & крест & да & 5,0 & 17,5 & $\square+\square$ & $\begin{array}{c}\text { по всей поверх- } \\
\text { ности }\end{array}$ & $\mathrm{I} / 1$ \\
\hline 1 & 10 & $\begin{array}{c}\text { части чаши и } \\
\text { отделения } \\
\text { утрачены }\end{array}$ & крест & да & 10,5 & $? ?$ & $\square+\wedge$ & $\begin{array}{c}\text { срез венчика, } \\
\text { «поясок», бок } \\
\text { ножек }\end{array}$ & $\mathrm{I} / 4$ \\
\hline 4 & 3 & $\begin{array}{l}\text { форма восста- } \\
\text { навлива-ется }\end{array}$ & $\begin{array}{c}\text { полый } \\
\text { крест }\end{array}$ & нет & 8,4 & 17,5 & $\wedge$ & срез венчика & II $/ 3$ \\
\hline 4 & 4 & $\begin{array}{c}\text { часть чаши, } \\
\text { венчика и но- } \\
\text { жек утрачены } \\
\end{array}$ & крест & да & 9,2 & 16,5 & нет & нет & $\mathrm{I} / 5$ \\
\hline 4 & 5 & целая & $\begin{array}{c}4 \text { раздель- } \\
\text { ных (d - } \\
3 \mathrm{~cm}) \\
\end{array}$ & да & 8,7 & 17 & $\square+\square$ & $\begin{array}{l}\text { срез венчика, } \\
\text { чаша снаружи }\end{array}$ & $\mathrm{VI} / 2$ \\
\hline 4 & 6 & фрагменты & $\begin{array}{c}\text { полый } \\
\text { крест }\end{array}$ & $? ?$ & $? ?$ & $? ?$ & $\square$ & $\begin{array}{l}\text { срез венчика, } \\
\text { чаша, ножки }\end{array}$ & II? \\
\hline 4 & 7 & целая & $\begin{array}{c}4 \text { раздель- } \\
\text { ных }\end{array}$ & $\begin{array}{c}\text { да, фи- } \\
\text { гурная } \\
\text { «ручка» }\end{array}$ & 8 & 19,3 & $\wedge, \square+9$ & $\begin{array}{l}\text { срез венчика, } \\
\text { чаша снаружи }\end{array}$ & $\mathrm{VI} / 2$ \\
\hline 4 & 8 & целая & $\begin{array}{c}\text { полый } \\
\text { крест }\end{array}$ & да & 13 & 17 & $\wedge+\boldsymbol{\Lambda}$ & $\begin{array}{c}\text { срез венчика, } \\
\text { «поясок», бок } \\
\text { ножек } \\
\end{array}$ & $\mathrm{II} / 2$ \\
\hline 4 & 11 & целая & $\begin{array}{c}\text { полый } \\
\text { крест }\end{array}$ & да & 12 & 15,5 & $\wedge+\boldsymbol{\Delta}$ & $\begin{array}{c}\text { срез венчика, } \\
\text { чаша снаружи, } \\
\text { низ ножек }\end{array}$ & II/1 \\
\hline 4 & 12 & целая & $\begin{array}{c}\text { круглая } \\
(\mathrm{d}-8 \mathrm{~cm})\end{array}$ & нет & 11,5 & 14 & $\wedge$ & «Поясок» & $\mathrm{X} / 3$ \\
\hline
\end{tabular}

Примечание. $\approx$ - шнур; < - прочерченный орнамент; • - круглый штамп; 9 - спиральный штамп; • - точечный орнамент; $\boldsymbol{\Delta}$ - треугольный штамп; $\cup$ - ногтевые вдавления; $\boldsymbol{\cdots}$ - зубчатый штамп.

Таблица 2 - Типология курильниц суворовской катакомбной культуры

\begin{tabular}{|c|c|c|}
\hline Тип/подтип & Описание & Схема орнаментации \\
\hline Тип I & чаша на монолитном четырехлепестковом поддоне & \\
\hline Подтип 1 & $\begin{array}{l}\text { орнамент по всей поверхности чаши, иногда за ис- } \\
\text { ключением боковой поверхности ножек, нанесенный } \\
\text { оттисками шнура и различных видов штампа }\end{array}$ & \\
\hline Подтип 2 & $\begin{array}{l}\text { орнамент по верхнему срезу венчика и боковой по- } \\
\text { верхности чаши и ножек, нанесенный прочерченными } \\
\text { линиями и различных видов штампа }\end{array}$ & \\
\hline Подтип 3 & $\begin{array}{l}\text { орнамент по верхнему срезу венчика, иногда на верх- } \\
\text { ней части боковой поверхности чаши отдельными де- } \\
\text { коративными элементами }\end{array}$ & $m \Delta \Delta 0 \cdot \cup$ \\
\hline Подтип 5 & отсутствие орнамента & $\frac{\Omega}{\Sigma}+\varnothing$ \\
\hline
\end{tabular}




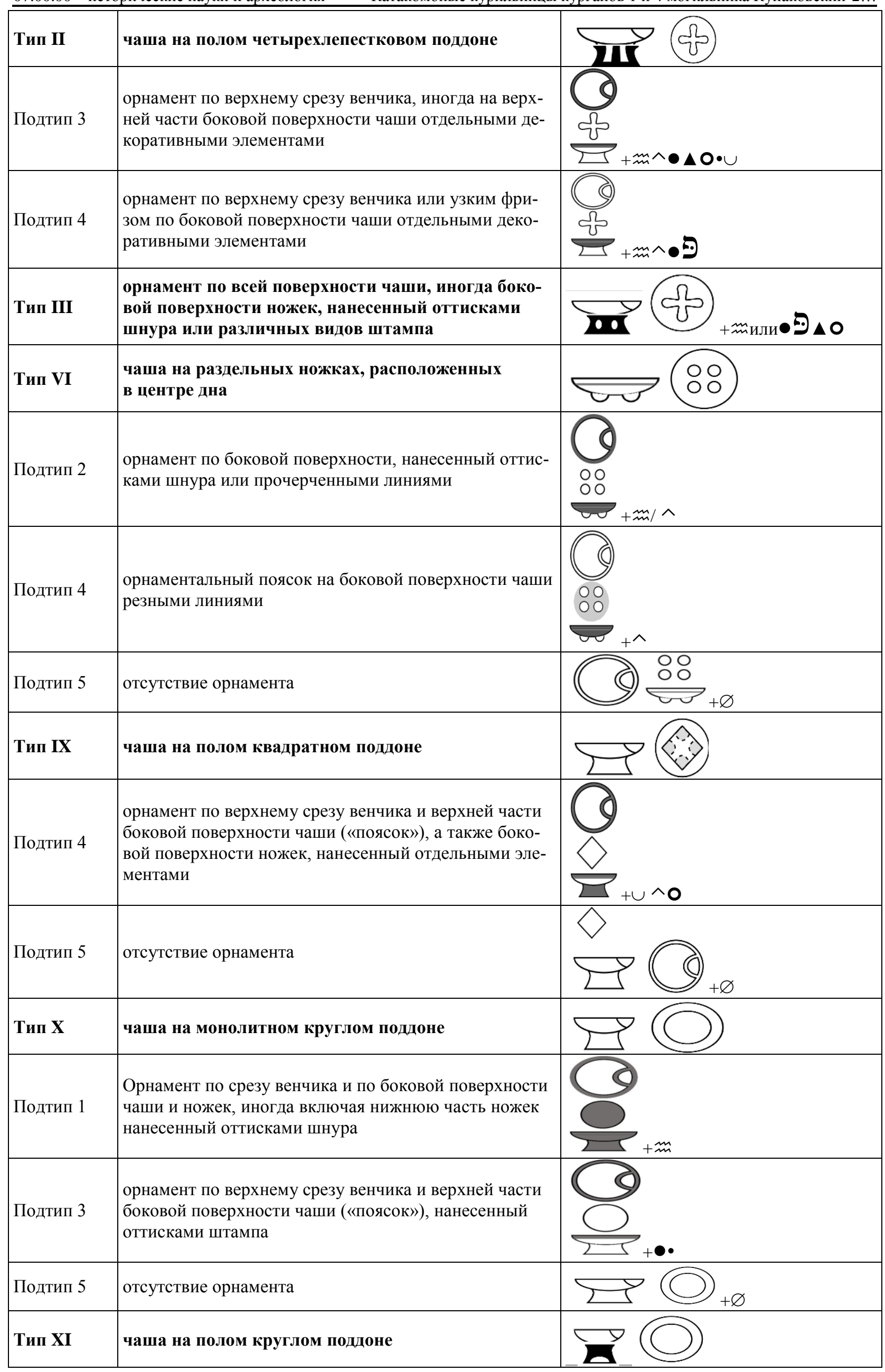


Так, курган 1 содержал курильницы типа I - сосуды на четырехлепестковом цельном (п. 6, 8, 10) или полом $($ п. 4,7$)$ поддоне - типа II. Все они имеют отделение, в одном случае (п. 6) оно дополняется двумя сквозными отверстиями в стенке чаши. Орнаментация единообразна: оттиски шнура и разных видов штампа (в одном случае (п. 7) вместо шнура использованы прочерченные линии); на чаше из п. 10 декор состоит из точечных вдавлений. По зонам локализации декора сосуды относятся к подтипам: 1 верхний срез венчика, боковая поверхность чаши, нижняя плоскость ножек (п. 6, 8); 2 - верхний срез венчика и боковая поверхность чаши (п. 7); 3 - верхний срез венчика и поясок на боковой поверхности чаши (п. 4); 4 - верхний срез венчика, поясок на боковой поверхности чаши и боковые плоскости ножек (п. 10) (табл. 1).

Курильницы из кургана 4 отличаются большим типологическим разнообразием (табл. 1). Кроме описанных уже типов I (п. 4) и II (п. 3, 8, 11) здесь присутствуют находки типов VI - чаша на четырех раздельных ножках в центре дна чаши $($ п. 5,6$)$ и X - курильница на круглом монолитном поддоне (п. 12). Все сосуды за исключением двух (п. 3 и 12) имеют внутреннее отделение, в одном случае оно дополняется фигурной «ручкой» с двумя вертикальными сквозными отверстиями (п. 7).

Важно отличать такую «ручку» от налепов со сквозными отверстиями, которые встречаются на раннекатакомбных курильницах на раздельных ножках, расположенных по краю дна (тип VII) [10, рис. 2]. На чаше из п. 7 «ручка» имеет острый угол наклона по отношению к стенке сосуда (прикреплена «сверху вниз»), на раннекатакомбных экземплярах угол наклона тупой (т.е. крепление «снизу вверх). Кроме того, раннекатакомбных налепов обычно два, и они разнесены на некоторое расстояние друг от друга. Такие курильницы не имеют отделения.

Орнаментация курильниц из кургана 4 типична для древностей СувКК, что отражает их отличие на уровне подтипов от ритуальных чаш других катакомбных культур. По сравнению с находками из кургана 1 здесь почти не использовались оттиски шнура (кроме п. 5 и 7), зато активно применялись прочерченные линии $($ п. $3,8,12)$ и оттиски отдельных видов штампа (п. 11). Наиболее показательна специфика зональности орнамента. Только одна курильница покрыта орнаментом по всей внешней поверхности, за исключением боковой плоскости ножек (п. 11) подтип 1; на двух декор нанесен на верхний срез венчика и боковую поверхность ножек (п. 5 и 7) подтип 2; украшен верхний срез венчика (п. 3), дополняемый орнаментальным пояском на боковой поверхности чаши (п. 12) - подтип 3; верхний срез венчика, орнаментальный поясок и боковая поверхность ножек (п. 8) - подтип 4; одна курильница не орнаментирована (п. 4) - подтип 5 (табл. 1).

Уникальность описанных материалов могильника Кунаковский-2 заключается в том, что здесь мы располагаем стратиграфической колонкой катакомбных погребений, которые являются как основными, так и впускными для нескольких насыпей. На основе типологического разнообразия этих ритуальных чаш и стратиграфических данных можно констатировать последовательность их использования в катакомбном погребальном обряде.
В кургане 1 в центре находилось два катакомбных погребения (9 и 10). С ними связаны фрагменты материкового выкида, зафиксированные на уровне погребенной почвы в южном и частично северном профиле центральной бровки (рис. 2). Вероятно, эти фрагменты представляли собой целую линзу, которая была нарушена при сооружении катакомбного погребения 3, впущенного в первую насыпь. Взаимное расположение камер этих погребений (рис. 1, 6: 2) позволяет предположить, что они были сооружены единовременно. Эта сложная двухкамерная катакомбная конструкция была основной для первоначальной насыпи. Здесь найдена курильница типа I/4. Дальнейшее строительство кургана связано с сооружением погребения 8, которое сопровождалось возведением второй насыпи, сместившей центр кургана к западу (рис. 1, 2). В полы этой насыпи были по кругу впущены погребения 4, 6, 7 и детское погребение 5 без курильницы. Характерно, что все эти стратиграфически не разделяемые погребения этого кургана содержали курильницы сходных типов (I, II), что подтверждает относительную синхронность совершения захоронений (рис. 16).

Стратиграфическая колонка погребений кургана 4, несмотря на неисследованную южную полу, выстраивается следующим образом. Вероятно, курган был полностью возведен в эпоху средней бронзы, но в несколько этапов, которые четко маркируются погребениями с курильницами разных типов. Первая насыпь была сравнительно небольшой: не более полуметра высотой и 5-6 м в диаметре. Она относится к погребению, от которого сохранился лишь небольшой фрагмент материкового выкида, лежавший на погребенной почве (рис. 8, 9). Возможно, основное захоронение было разрушено более поздними могилами. Затем было сооружено раннекатакомбное погребение 3, сопровождавшееся мощным материковым выкидом (рис. 8, 9). Возведенная над ним вторая насыпь существенно увеличила высоту и диаметр кургана. В погребении 3 найдена курильница без отделения типа II/3. В северную полу второй насыпи было впущено захоронение 8 с курильницей типа II/4, имеющей орнаментацию характерную только для суворовской катакомбной культуры. В южную часть этой же насыпи было впущено погребение 4, содержавшее ритуальную чашу типа I/5. Входная яма этого погребения была перекрыта мощным материковым выкидом, связанным со следующим этапом курганного строительства. Тогда были сооружены погребения 10 (детское) и 11 (взрослое, с курильницей типа II/1), над которыми была сделана третья насыпь, в результате чего центр кургана сместился к юго-юго-западу (рис. 8). Входные ямы этих погребений смыкались, что не позволило установить их хронологическую последовательность; сходство обряда, сопровождающего инвентаря, подстилки и мощность материкового выкида, связанного с ними, дает возможность предположить их одновременность. Впускным захоронением для этой насыпи, нарушившим камеру п. 10, стало п. 12 с ритуальной чашей типа X/3. С самым поздним этапом строительства кургана связаны погребения 7, 6 и 5 с курильницами типов VI/2 и VI/1 (в п. 6 чаша представлена во фрагментах - тип не устанавливается), сгруппированные в южной части. Самым ранним из них яв- 
ляется погребение 7 - возможно, оно было основным (наряду с п. 9) для четвертой насыпи. С этим погребением связан материковый выкид, перекрывший третью насыпь к востоку от захоронения. Глубина залегания этого выкида одинакова с двумя другими линзами, связанными с погребением 9 и также перекрывающими третью насыпь на ее западной и южной границах (рис. 8, 9). В четвертую насыпь было впущено погребение 6, обнаруженное по общему с погребением 7 аморфному пятну заполнения входной ямы. Заполнение ям двух погребений отличались друг от друга, что свидетельствует об их разновременности. Доказательством более позднего возраста погребения 6 является то обстоятельство, что закладной камень был примазан глиной прямо к черноземному заполнению погребения 7 (рис. 10: 4). Самым последним катакомбным погребением с курильницей стало погребение 5, впущенное в южную полу четвертой насыпи и перекрывшее камеру погребения 6 (рис. 8). В результате выстраивается показательная колонка типов ритуальных чаш (рис. 17): первым появляется тип II, который используется довольно долго, дополняемый типом I, причем варианты орнаментации меняются (подтипы 5, 1); поздние этапы функционирования курганной насыпи связаны с типами X и VI.

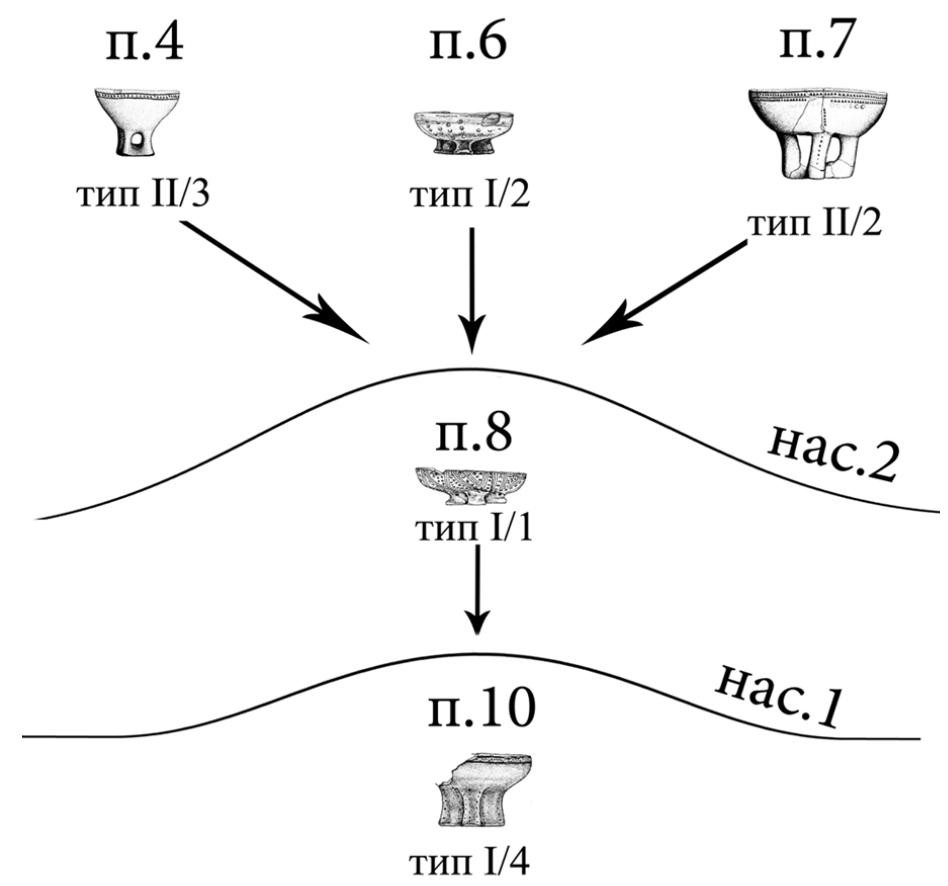

Рисунок 16 - Стратиграфическое положение курильниц кургана 1 могильника Кунаковский-2

Стратиграфические наблюдения в двух курганах могильника Кунаковский-2 позволяют подтвердить выводы, полученные на основе анализа сопровождающих наборов в памятниках восточноманычской катакомбной культуры (ВМКК), о возможности выделения двух этапов внутри развитых катакомбных культур [9; 11], и применить их к материалам суворовской катакомбной культуры. Использование курильниц в качестве критерия периодизации катакомбных культур очень перспективно. Погребальный обряд СувКК пока изучен слабо, что не дает оснований для хронологического разделения культуры. Отсутствие абсолютных датировок для этой культуры также затрудняет выделение этапов развития. Однако очевидное разнообразие основных характеристик памятников позволило выделить шесть локальных групп [3]. Несомненно, что должны быть и временные отличия, которые возможно будет выделить с помощью хронологически дифференцируемых категорий инвентаря, в частности курильниц.

Курильницы могильника Кунаковский-2 отражают ситуацию характерную для всей суворовской катакомбной культуры. Самыми распространенными здесь являются типы I и II с богатой орнаментацией, которые в наибольшей степени представлены в суворовских древностях (табл. 2), так же как и в других синхронных катакомбных культурах. Они маркируют более ранний горизонт катакомбных погребений.
Позднее появляются неорнаментированные курильницы типов I и II. Их более поздний возраст подтверждается появлением четырехрожкового бисера, который в модифицированном виде переходит в посткатакомбное время [12, рис. 118]. Следующий этап использования курганной насыпи связан с появлением типов VI и X, число таких чаш существенно меньше, что связано с их более поздним периодом существования, когда традиция использования специфических ритуальных чаш в целом начинает себя изживать [11, с. 48]. Дополнительным аргументом позднего возраста курильницы типа VI является присутствие в погребении вместе с ней трехручного сосуда с выделенным узким горлом. Наиболее близкие аналогии этому сосуду мы находим в древностях восточноманычской катакомбной культуры $[13$, с. 160 , рис. 4: 2]. В целом, традиция изготовления сосудов (так называемых «амфорок») с несколькими ручками на низком горле маркирует поздний этап катакомбных древностей $[14$, с. 84]. Обращает на себя внимание отсутствие в описанных погребениях курильниц типа IX, который является своеобразным маркером суворовской катакомбной культуры (такая курильница найдена только в одном погребении соседнего могильника Кунаковский-1). Вероятно, это связано с пограничным положением могильника между ареалом восточноманычской и суворовской катакомбных культур. 


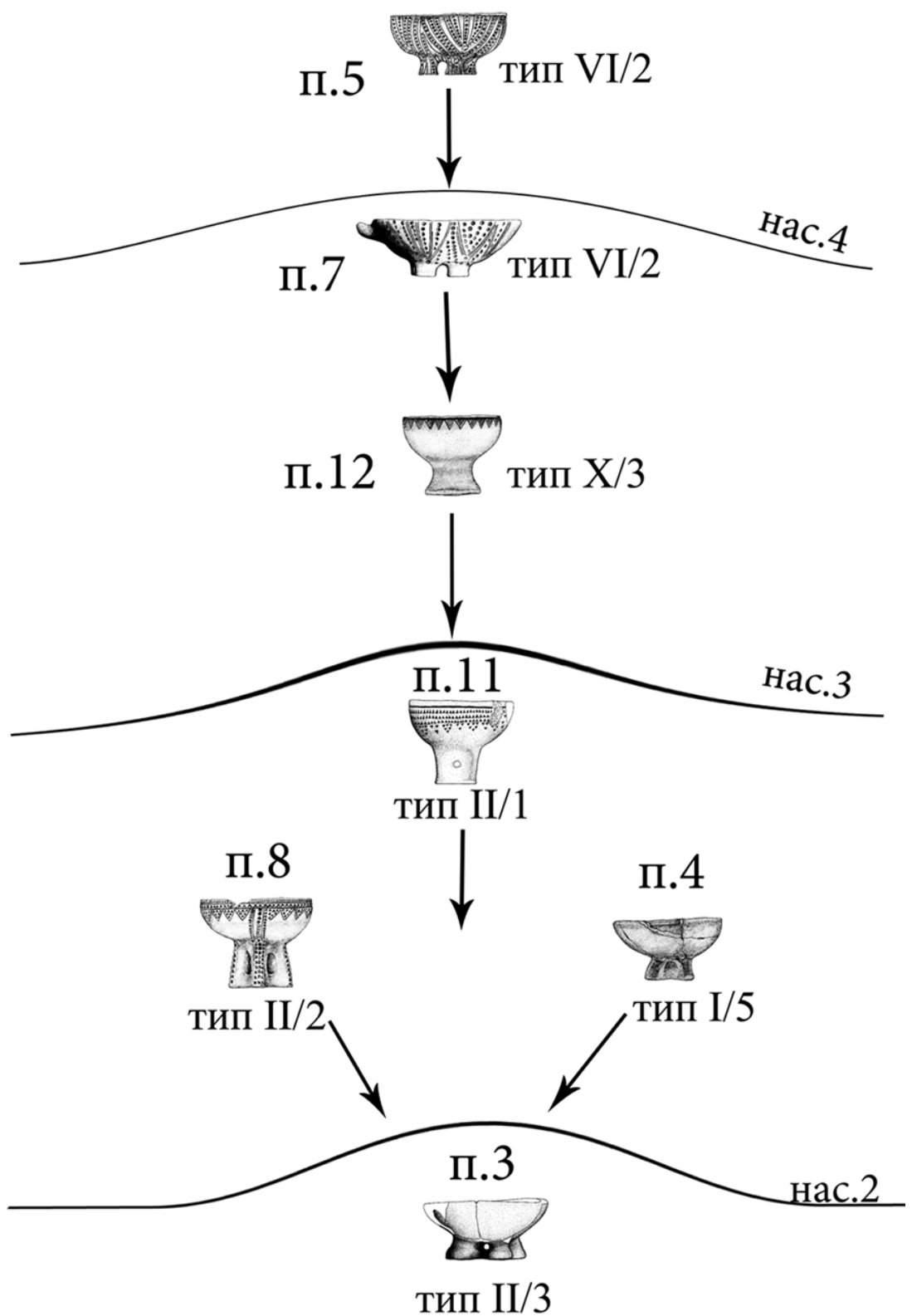

Рисунок 17 - Стратиграфическое положение курильниц кургана 4 могильника Кунаковский-2

Перспективным, на наш взгляд, является сопоставление черт погребального обряда и инвентаря восточноманычской и суворовской катакомбной культур, что позволит выявить связи между ними. В данной ситуации материалы могильника Кунаковский-2 являются наиболее показательными, т.к. он находится на границе двух культур. Сопоставление типов курильниц позволяет обозначить такие влияния, отражающие эволюцию использования ритуальных чаш в горизонте развитых катакомбных культур.

Таким образом, результаты стратиграфического анализа погребений с курильницами разных типов позволяют довольно уверенно применить к материалам суворовской катакомбной культуры периодизацию, предложенную на материалах ВМКК. На наш взгляд, они наглядно демонстрируют существование двух этапов в эволюции курильниц и, соответственно, развитии СувКК. Данный тезис, несомненно, нуждается в проверке на основе анализа других категорий инвентаря, однако даже эти первоначальные данные убеждают в обоснованности предлагаемой периодизации.
Автор выражает глубокую признательность руководству и сотрудникам ГУП «Наследие» и лично А.А. Калмыкову за возможность ознакомиться $и$ разрешение опубликовать материалы из раскопок в Ставропольском крае.

\section{Список литературы:}

1. Нечитайло А.Л. Верхнее Прикубанье в эпоху средней бронзы: автореф. дис. ... канд. ист. наук. Киев, 1973. 24 с.

2. Нечитайло А.Л. Верхнее Прикубанье в бронзовом веке. Киев: Наукова думка, 1978. 151 с.

3. Клещенко А.А. Суворовская катакомбная культура: предварительная характеристика // Краткие сообщения Института археологии. 2013. № 228. С. $171-190$.

4. Кияшко А.В. Происхождение катакомбной культуры Нижнего Подонья. Волгоград: Изд-во ВГУ, 1999. 182 c.

5. Андреева М.В. Восточноманычская катакомбная культура (анализ материалов погребальных памятников). М.: Таус, 2014. 271 с.

6. Матюхин А.Д. Отчет об археологических раскопках курганных могильников «Кунаковский-1», 
«Кунаковский-2», «Тоннельный-6», «Невинномысский-1» на территории Андроповского и Кочубеевского районов Ставропольского края в 2005 году // Архив ИА РАН. Р-1. № 29029, 29030-29031.

7. Панасюк Н.В. Курильницы суворовской катакомбной культуры // Краткие сообщения Института археологии. 2015. № 237. С. 126-141.

8. Панасюк Н.В. Опыт типологического анализа катакомбных курильниц // Проблеми дослідження пам'яток археології Східної України: материалы II-ї Луганської міжнародної історико-археологічної конференції, присвяченої 85-річчю Луганського обласного краєзнавчого музею / отв. ред. В.В. Отрощенко. Луганск: Шлях, 2005. С. 63-65.

9. Панасюк Н.В., Мимоход Р.А. Поздние курильницы восточноманычской катакомбной культуры // Древний Кавказ: ретроспекция культур: тезисы докладов XXIII Крупновских чтений по археологии Северного Кавказа / отв. ред. Л.Т. Яблонский. М.: ИА РАН, 2004. С. 140-142.
10. Панасюк Н.В. Раннекатакомбные курильницы степного Предкавказья // Российская археология. 2010. № 2. C. 25-38.

11. Панасюк Н.В. Курильницы восточноманычской катакомбной культуры как критерий периодизации // Проблемы периодизации и хронологии в археологии эпохи раннего металла Восточной Европы: материалы тематической науч. конф. / отв. ред. Е.А. Черленок. СПб.: Скифия-принт, 2013. С. 44-49.

12. Мимоход Р.А. Лолинская культура. СевероЗападный Прикаспий на рубеже среднего и позднего периодов бронзового века: материалы охранных археологических исследований. Т. 16. М.: ИА РАН, $2013.567 \mathrm{c}$.

13. Державин В.Л. Погребения эпохи бронзы из курганов у хут. Веселая Роща (по материалам экспедиции 1980 г.) // Древности Ставрополья. М.: Наука, 1989. С. $125-194$.

14. Смирнов А.М. Курганы и катакомбы эпохи бронзы на Северском Донце. М.: ИА РАН, 1996. 181 с.

\section{CATACOMB INCENSE BURNERS OF KURGANS 1 AND 4 OF KOUNAKOVSKY-2 (ON THE EXAMPLE OF ANDROPOVSKIY DISTRICT, STAVROPOL REGION)}

\section{(C) 2018}

Panasyuk Nathalia Victorovna, candidate of historical sciences, senior lecturer of World History Department People' Friendship University of Russia (Moscow, Russian Federation)

\footnotetext{
Abstract. The author considers the data of Suvorov catacomb culture burials with incense burners, found in kurgans Kounakovsky-2, explored by the expedition of the «Nasledie» in Stavropol Region in 2005. The artefacts from burials of two kurgans (1 and 4) illustrate the typological variety of the catacomb ritual bowls. In addition these kurgans demonstrate good stratigraphy of burials that allows seeing the incense burner's evolution. Such evolution has been already created on data of Vostochnomanych catacomb culture, when early and late types were identified. Suvorov catacomb culture's incense burners of type I, II, VI, X are found in kurgans Kounakovsky-2, one item belongs to the early catacomb period. Stratigraphic data of kurgan 1 indicates almost synchronic construction of the burials, as evidenced by the finds of typologically close incense burners. Kurgan 4 was built at least in four steps, which are illustrated by ritual bowls of early (I, II) and late (VI, X) stages. As a result the authors of the paper justify that Suvorov catacomb culture may be divided in two periods of development, marked by different types of incense burners.

Keywords: archaeological excavations; kurgans; Suvorov catacomb culture; Early catacomb culture; Vostochnomanych catacomb culture; incense burners; typology; stratigraphy; funeral rite's attribute; chronology of archeological culture; Middle Bronze age; Stavropol Region.
}

УДК 902.03

Статья поступила в редакцию 03.05.2018

\section{КУЛЬТУРНАЯ АТРИБУЦИЯ ЖИЛИЩА-МАСТЕРСКОЙ НА ПОСЕЛЕНИИ ТАЛДЫСАЙ НА ОСНОВЕ АНАЛИЗА КЕРАМИКИ}

(C) 2018

Ермолаева Антонина Сергеевна, ведущий научный сотрудник отдела первобытной археологии Калиева Жанаргуль Сериковна, научный сотрудник отдела первобытной археологии Дубягина Екатерина Викторовна, младший научный сотрудник отдела первобытной археологии Институт археологии имени А.Х. Маргулана (г. Алматы, Республика Казахстан)

Аннотаџия. В статье представлена характеристика керамической коллекции из жилища-мастерской поселения металлургов Талдысай, имевшего один период заселения и принадлежавшего к петровской археологической культуре (нуртайский тип памятников для Центрального Казахстана). В предыдущие годы исследований делались попытки на основе керамического материала произвести определение культурной принадлежности теплотехнических сооружений наземного и шахтного типов в жилищно-производственных комплексах, функционировавших в разные хронологические периоды и содержавших разнокультурные материалы. Настоящая публикация является началом работы по систематизации всего массива накопленных керамических материалов поселения, из которых керамика однослойного жилища-мастерской, функционировавшей с начала организации металлопроизводства на поселении, является эталонной и служит репером при проведении классификации всего массива накопленных керамических коллекций. Для анализа из более чем 